\title{
What works to increase charitable donations? \\ A meta-review with meta-meta-analysis
}

\begin{abstract}
Alexander K. Saeri ${ }^{1,2}$, Peter Slattery ${ }^{1,2}$, Joannie Lee ${ }^{3}$, Thomas Houlden ${ }^{3}$, Neil Farr ${ }^{4}$, Romy Gelber $^{3}$, Jake Stone ${ }^{5}$, Lee Huuskes ${ }^{6}$, Shane Timmons ${ }^{7}$, Kai Windle ${ }^{5}$, Luke Spajic ${ }^{8}$, Luke Freeman $^{9}$, David Moss ${ }^{10}$, Jon Behar ${ }^{11}$, Stefan Schubert ${ }^{12}$, Emily A. C. Grundy ${ }^{1,2}$, Michael

$$
\text { Zorker }^{2}
$$
\end{abstract}

${ }^{1}$ BehaviourWorks Australia, Monash Sustainable Development Institute, Monash University

${ }^{2}$ Rapid Effective Action Development Initiative (READI)

${ }^{3}$ University of New South Wales

${ }^{4}$ Southern Cross Care

${ }^{5}$ University of Sydney

${ }^{6}$ University of Wollongong

${ }^{7}$ Economic and Social Research Institute

${ }^{8}$ University of Adelaide

${ }^{9}$ Giving What We Can

${ }^{10}$ Rethink Priorities

${ }^{11}$ The Life You Can Save

${ }^{12}$ University of Oxford 


\section{Author note}

Correspondence concerning this article should be addressed to Alexander Saeri,

BehaviourWorks Australia, Monash Sustainable Development Institute, Monash University, 8

Scenic Blvd, Clayton VIC 3800 Australia. Email: alexander.saeri@monash.edu

\section{Declaration}

The authors did not receive support from any organization for the submitted work.

No funding was received to assist with the preparation of this manuscript.

No funding was received for conducting this study.

No funds, grants, or other support was received.

\section{Acknowledgements}

We gratefully acknowledge the assistance of Lucius Caviola and David Reinstein, and several anonymous reviewers for their efforts in maximising the rigor and usefulness of this manuscript 


\section{Abstract}

Many charities rely on donations to support their work addressing some of the world's most pressing problems. We conducted a meta-review to determine what interventions work to increase charitable donations. We found 21 systematic reviews incorporating 1,339 primary studies and over 2,139,938 participants. Our meta-meta-analysis estimated the average effect of an intervention on charitable donation size and incidence: $r=0.08$ (95\% CI [0.03, 0.12]). Due to limitations in the included systematic reviews, we are not certain this estimate reflects the true overall effect size. The most robust evidence found suggests charities could increase donations by (1) emphasising individual beneficiaries, (2) increasing the visibility of donations, (3) describing the impact of the donation, and (4) enacting or promoting tax-deductibility of the charity. We make recommendations for improving primary research and reviews about charitable donations, and how to apply the meta-review findings to increase charitable donations.

\section{Keywords}

Philanthropy, Charity, Behaviour Change, Prosocial Behaviour, Overview of Reviews, Meta-Review, Meta-Meta-Analysis 


\section{Introduction}

Charities address some of the world's most important and neglected problems (MacAskill, 2015; Singer, 2019). Some of the highest-impact (e.g., Against Malaria Foundation; GiveWell, 2021) and most famous (e.g., American Red Cross; Charity Navigator, 2022) charities rely on asking people to give money for no tangible reward (Bendapudi et al., 1996). As a result, effective fundraising is both critical and challenging for nonprofits. We conduct a meta-review of systematic reviews to identify 'what works' to promote charitable donations. Our aim is to provide practitioners and researchers with a resource for identifying which interventions have been investigated, which ones work, and which do not. By charitable donations, we mean the altruistic transfer of money from a person to an organisation that helps people in need (after Bekkers \& Wiepking, 2011b). We catalogue systematic reviews because they: (a) search for and assess the evidence about which interventions work (Hulland \& Houston, 2020; Stanley et al., 2018), (b) describe the effectiveness of interventions in a way that can be systematically compared, and (c) help practitioners and researchers understand which interventions have good external validity and generalisability (Higgins et al., 2019; Stanley et al., 2018). By synthesising systematic reviews, we can provide stronger recommendations for evidence-informed decisionmaking than by reviewing individual studies alone (HM Treasury, 2020).

\section{This Meta-Review Investigates Which Hypothesised Drivers of Charitable Giving Have}

\section{Robust Support}

There are several existing reviews of evidence-based charitable promotion (e.g., Bekkers \& Wiepking, 2011a, 2011b; Bendapudi et al., 1996; Oppenheimer \& Olivola, 2010; Wiepking \& Bekkers, 2012). We build on these reviews by conducting a meta-review, also known as an 
umbrella review or overview of reviews. Meta-reviews are similar to systematic reviews because they systematically search for and appraise existing research to answer a focused research question. A systematic review aggregates primary studies, but a meta-review aggregates systematic reviews. This allows meta-reviews to cover a wider scope than traditional systematic reviews (Becker \& Oxman, 2011). Systematic reviews employ a comprehensive, reproducible search strategy to identify primary research into the effects of an intervention (e.g., providing information about recipients) on a specific outcome (e.g., size of donation) across contexts, while also assessing which situational factors influence those effects. Meta-analyses may form part of a systematic review and use statistics to estimate the average strength of those effects (Higgins et al., 2019). Research standards and practices differ across disciplines, and even within a discipline (e.g., psychology), results on 'what works' to increase charitable donations can conflict due to inconsistent pre-registration, participant demographics, and publication bias (Open Science Collaboration, 2015). Charitable donation as a behaviour is therefore a good fit for a meta-review because useful research on the topic is fragmented across many disciplines including marketing, economics, psychology, and others (Bekkers \& Wiepking, 2011b; Bendapudi et al., 1996; Mazodier et al., 2020; Pham \& Septianto, 2019; Rothschild, 1979; Septianto et al., 2020; Wallace et al., 2017). Our meta-review aggregates systematic reviews on charitable giving. Where included systematic reviews are accompanied by a meta-analysis, we aggregate those meta-analyses into a meta-meta-analysis to quantify and compare the strength of interventions to promote charitable giving.

We organise the presentation of results from our meta-review using an established and highly-cited model of drivers for charitable donations (Bekkers \& Wiepking, 2011b). This narrative review proposed a model where donors are more likely to give when they are prompted 
to donate (solicitation) to a cause they know about (awareness of need), if the cost is low enough (costs and benefits) for the effect it has on society (altruism). According to this model, people also donate if they think doing so will make them look good in the eyes of others (reputation), make them feel good (psychological benefits), align with what is important to them (values), and make a meaningful difference (efficacy). Bekkers and Wiepking classified different interventions found in primary research into one or more of these drivers, for example, by discussing how tax deductibility decreases the costs of donation. However, unlike a systematic review, their narrative review approach did not account for publication bias or pre-register inclusion and exclusion criteria; it also did not estimate the relative effectiveness of each driver for influencing charitable donations. In our meta-review, we seek to comprehensively identify all interventions that increase charitable behaviour and that have been the focus of an existing systematic review. Because systematic reviews often include a meta-analysis, which summarises the quantitative effect size or 'strength' of an intervention on charitable donation behaviour, our meta-review will also assess the effectiveness of each driver (e.g., awareness, costs and benefits) in increasing charitable donation behaviour. In this review, we use the Bekkers and Wiepking (2011b) classification to identify which drivers have been the most studied, which have not, and which drivers appear to most influence charitable donation behaviour.

\section{Aim}

In this meta-review, we aim to:

1. synthesise the systematic reviews on interventions designed to promote charitable donations across disciplines 
2. combine the quantitative effect size estimates from meta-analyses included in the systematic reviews and use meta-meta-analysis to estimate the effectiveness of interventions to promote charitable donations

3. interpret the findings by classifying each intervention according to a widely-used model (Bekkers \& Wiepking, 2011b) and best-practice guidelines for evidence informed decision-making (Guyatt et al., 2011; Higgins et al., 2019)

\section{Method}

We conducted a meta-review of systematic reviews using established recommendations (Becker \& Oxman, 2011; Grant \& Booth, 2009; Khangura et al., 2012; Pollock et al., 2017; World Health Organisation, 2017) to synthesise the literature on how to increase charitable donations. We conducted a meta-meta-analysis on any meta-analyses reported in the included systematic reviews. A meta-meta-analytic approach was necessary because it permitted the use of all available information from the original meta-analyses to calculate a pooled effect, while accounting for variability at both the study and meta-analysis level. Our meta-review was prospectively registered on the Open Science Framework (also attached as web appendix; Blinded for review, 2019, July 14; rationale presented in discussion). Details of our search strategy including search strings, screening and selection of studies, data extraction and quality assessment, quantitative synthesis, and certainty assessment are presented in Supplementary File 1 and summarised below.

We searched Scopus, PsycINFO (Ovid), Web of Science, and Database of Abstracts of Reviews of Effects due to their broad but non-overlapping corpora, and their coverage of topic areas relevant for our research question. We conducted searches on July 17th, 2019 and March 4th, 2021. We developed terms for identifying systematic reviews informed by a comprehensive 
typology of review methods (Grant \& Booth, 2009). Terms for charitable donations as outcomes included: altruis*, charit*, philanthro*, donat*, pledge*, or non-profit. Titles and abstracts were screened in duplicate; full-text articles were screened in duplicate; and included papers were extracted in duplicate. Disputes were resolved by discussion between reviewers, consulting a senior member of the team, if necessary.

Our inclusion criteria were (1) systematic reviews, scoping reviews, or similar reproducible reviews (i.e., those with a reproducible method section describing a searching and screening procedure); (2) reviews describing monetary charitable donations; (3) reviews assessing any population of participants in any context; and (4) written in English (due to logistical constraints) and (5) peer reviewed (although no papers ended up being excluded on the basis of this criteria). Exclusion criteria were (1) primary research reporting new data (e.g., randomised experiments); (2) non-systematic reviews, theory papers, or narrative reviews; (3) reviews on cause-related marketing; and (4) reviews of other kinds of prosocial behaviour (e.g., honesty, non-financial donations). We also conducted forward and backward citation searching (Hinde \& Spackman, 2015) via Scopus with no subject or publication requirements. We developed a data extraction template to capture information from each included review, and assessed the quality of the included reviews using an abbreviated list of quality criteria drawn from AMSTAR 2 (Shea et al., 2017). We used the GRADE approach to assess the quality of the evidence across all reviews for each combination of intervention and outcome (Guyatt et al., 2011; Higgins et al., 2019; Hultcrantz et al., 2017). More information about and results of these quality assessments are available in Supplementary File 1.

Many, but not all, systematic reviews also conducted meta-analyses to quantify the size of effects on donations. So we could compare the relative size of effects between these different 
meta-analyses, we conducted a meta-meta-analysis, or second-order meta-analysis (Hennessy et al., 2019; Schmidt \& Oh, 2013). These models are the best practice for synthesising effects across different meta-analyses because they can compare effect sizes on a common metric while accounting for variability both within- and between-reviews (Hennessy et al., 2019; Schmidt \& Oh, 2013). Our primary outcome was the overall pooled effect size of intervention on donation size. A secondary outcome was donation incidence - whether a donation of any size was provided-because many reviews reported on this dichotomous outcome. We extracted quantitative estimates from reviews that included meta-analyses and converted them to the most commonly used metric ( $r$ ) using the compute.es package (Del Re, 2020) in $R$ ( $R$ Core Team, 2020). We conducted a meta-meta-analysis using the metasem package (Cheung, 2014) and msemtools packages (Conigrave, 2019). We used random effects meta-analyses to calculate pooled effects for each mechanism and each outcome, then conducted moderation analyses to assess whether interventions were homogenous within mechanism and outcome. Raw data and code for reproducing the analyses are available at https://osf.io/465ej/?view_only=8f0ed79442cc4bc59feeb8d0880c6698.

\section{Results}

We organise the results as follows. First, we describe the reviews identified and included through the systematic search (Table 1 and Figure 1). Second, we present a meta-meta-analysis for the pooled effect of interventions on donation size and donation incidence (Figure 2). Third, we organise the included interventions using the model of drivers for charitable donations from Bekkers and Wiepking (2011b) to present a meta-meta-analysis of interventions for each driver (Figure 3) and describe each intervention in detail. 


\section{Records identified through systematic search}

As outlined in Figure 1, we screened 2,294 unique titles and abstracts. The team subsequently screened 60 full-texts for eligibility, 21 of which were included. Of the included systematic reviews, 15 included meta-analyses of either donation size or donation incidence. Characteristics and summaries of each included review are presented in Table 1. Most full-texts were excluded for being reviews that were not systematic (Weyant, 1996). Ten focused on prosocial behaviour but did not report charitable donations distinctly, so unique effects on that outcome could not be discerned (Nagel \& Waldmann, 2016). Six were on organisational behaviour that did not include charitable donations (e.g., the effects of nonprofits becoming more commercial; Hung, 2020) and five were primary research (Kinnunen \& Windmann, 2013) (e.g., randomised experiments; Kinnunen \& Windmann, 2013). Three reviews did not report prosocial outcomes (e.g., effects of advertising on sales; Assmus et al., 1984). Quality appraisal and certainty assessment of the included reviews were conducted consistent with our pre-registered protocol. Due to limitations of space, we report the results of these assessments in detail in Supplementary File 1, including a table describing the quality assessment (Table S1) and certainty assessment (Table S2). 


\section{Figure 1}

PRISMA Flow Diagram of Search and Filtering of Included Reviews

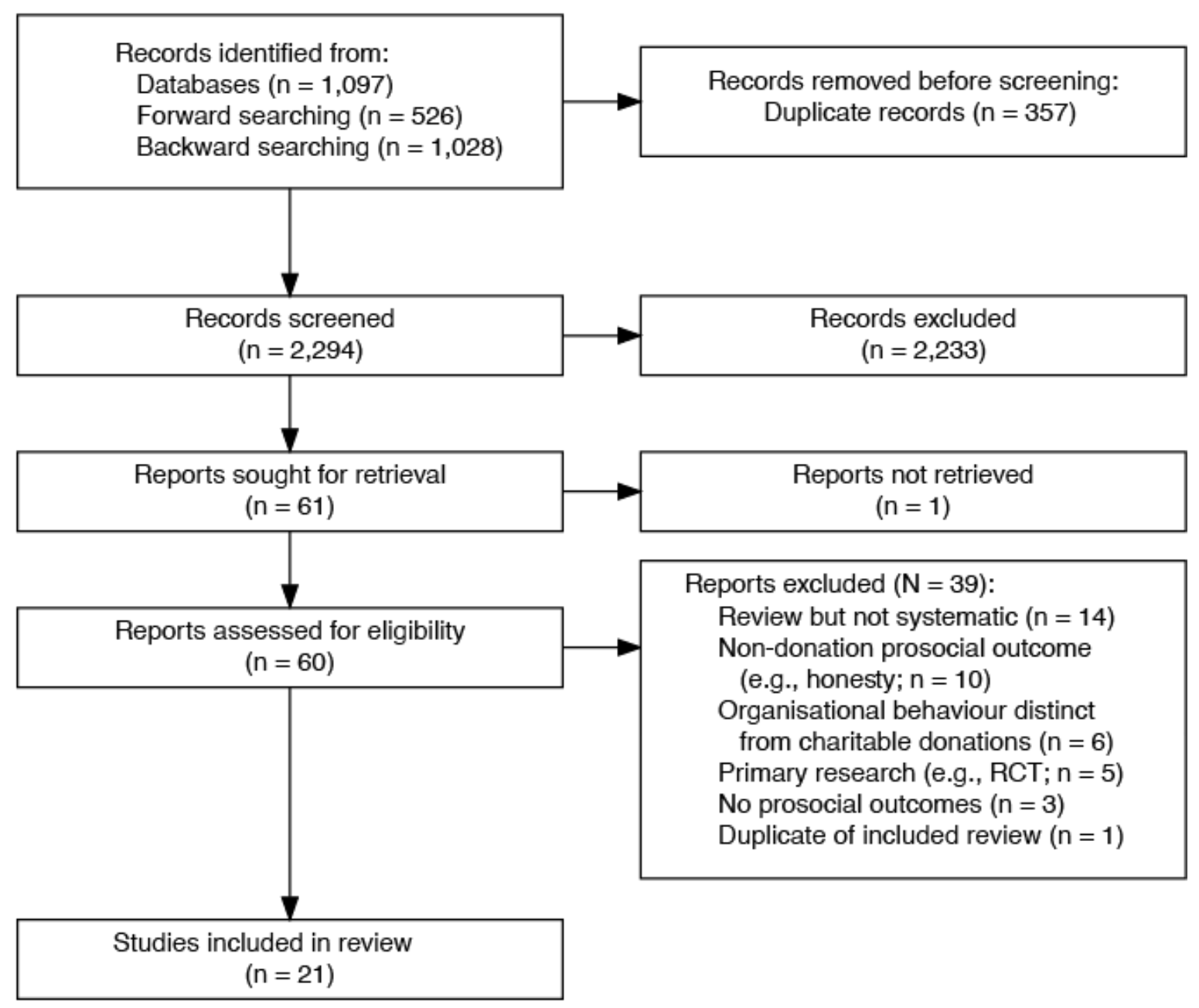


Insert Table 1 about here.

Table 1

Summary of Included Reviews

\begin{tabular}{|c|c|c|c|c|}
\hline Category / Review & $\begin{array}{c}\text { Included } \\
\text { in meta- } \\
\text { meta- } \\
\text { analysis }\end{array}$ & $\begin{array}{l}\text { Number } \\
\text { of studies } \\
(\mathrm{K})\end{array}$ & $\begin{array}{l}\text { Number of } \\
\text { participants } \\
\text { (N) }\end{array}$ & Summary of Results \\
\hline
\end{tabular}

Legitimizing Paltry Contributions: for example, saying "even a penny will help"

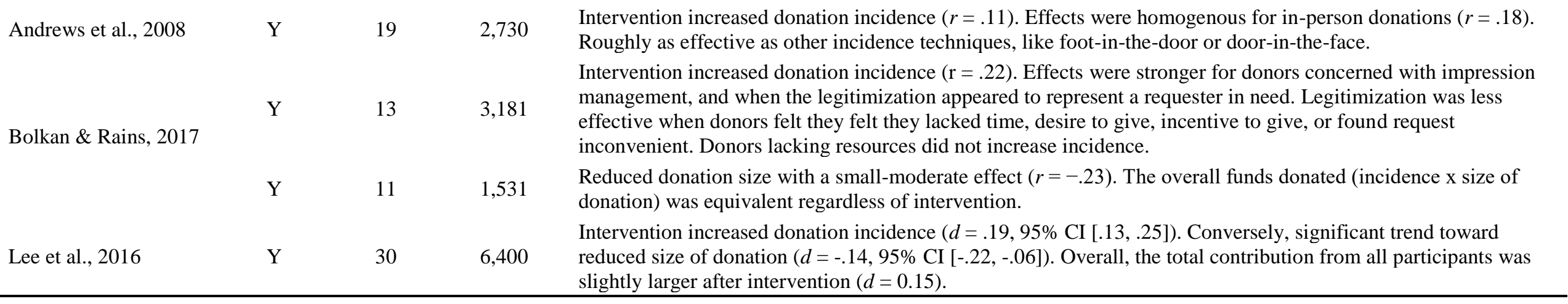

Observability: both real observation (e.g., experimental confederates) or artificial observation (e.g., watching eyes)

Bradley et al., 2018

Y

594,064

Real observation increased donation incidence $(r=0.15)$. No significant difference between effects on monetary donation and non-monetary prosocial behaviour $(p=.40)$. Taking all prosocial outcomes together (i.e., pooling monetary and non-monetary outcomes), effects were larger for repeat interactions, interactions with personal consequences, group social dilemmas (vs. 1:1 bargaining games), and where observation is more intense.

Artificial observation increased donation incidence (OR 1.39, 95\% CI $[1.02,1.91])$. No effect on size of donation $(\mathrm{d}=0.04, \mathrm{p}=0.55)$.

Nettle et al., 2013

Y

7

887

Northover et al., 2017

Y

21

19,512

No significant effect of surveillance cues on donation size $(\mathrm{d}=0.022,95 \% \mathrm{CI}[-0.08,0.13])$ or on the donation incidence $(\mathrm{OR}=0.15,95 \% \mathrm{CI}[-0.03,0.35])$

Artificial observation. Vote count: 15/16 short exposure studies increased donation incidence; 0/5 long exposure studies increased donation incidence. Difference between short and long exposure effects possibly due to habituation.

Sparks \& Barclay,

2013

$\mathrm{N}$

25

NR

Compassion fade / 'identifiable victim': Showing the donor one individual victim rather than a group of victims/recipients 


\begin{tabular}{|c|c|c|c|c|}
\hline Category / Review & $\begin{array}{l}\text { Included } \\
\text { in meta- } \\
\text { meta- } \\
\text { analysis }\end{array}$ & $\begin{array}{l}\text { Number } \\
\text { of studies } \\
\quad(\mathrm{K})\end{array}$ & $\begin{array}{l}\text { Number of } \\
\text { participants } \\
\quad(\mathrm{N})\end{array}$ & Summary of Results \\
\hline Butts et al., 2019 & $\mathrm{Y}$ & 41 & 13,259 & $\begin{array}{l}\text { Larger victim group decreased donation incidence intention and behaviour }(\mathrm{r}=-0.11) \text {. Effects mediated by } \\
\text { perceived impact and anticipated positive affect. A larger group of victims led to lower anticipated affect }(\mathrm{r}= \\
-0.12) \text { and lower perceived impact }(\mathrm{r}=-0.21) \text {, which, in turn, reduced incidence behaviour. Weaker effect for } \\
\text { certain, severe, and calamitous problems (famine) than uncertain, minor ones (no schoolbooks). }\end{array}$ \\
\hline
\end{tabular}

Prosocial media: Non-specific prosocial media (i.e., TV, movies, video games, music, or music videos with prosocial content)
Coyne et al., 2018
$\mathrm{Y}$
72
17,134
Prosocial media did not increase donation size $(r=0.09)$, but increased other prosocial behaviours and cognitions. May be due to specific behaviours (e.g., donating) frequently demonstrated in the media, and therefore, less likely to be imitated.

Crowding out: Side effects from government funding that might decrease donations from the public ('crowding out'), or attract people to donate ('crowding in')?

\begin{abstract}
de Wit \& Bekkers,
\end{abstract}
2017

Lu, 2016

$\mathrm{N}$
54

60

On average, $\$ 1$ increase in government support leads to $\$ 0.17$ decrease in private charitable donation size across all studies. In experiments, a $\$ 1$ increase leads to a $\$ 0.64$ decrease in private donation size. In archival or survey data, a $\$ 1$ increase leads to a $\$ 0.06$ increase in private donation size. Overall, no decisive evidence for government support to crowd out private charitable contributions.

No overall effects of government donations on private contributions (unweighted mean $=.03$ ). Crowding out is more likely in studies that control for endogeneity (e.g., those that use fixed effects or instrumental variables). Regardless, the effect sizes were too small to support either crowding-out or crowding-in

Moderators in dictator games: One participant is given some money and provided an opportunity to give to another participant with no incentive or response from recipient

Donors provided with funds donate $28 \%$ of those funds. Overall donation incidence of $64 \%$ (any size).

Controlling for other factors, donations size was higher for older donors, multiple recipients, deserving recipients, recipients who had earned the money, and when donations attracted some type of multiplier. Donation size was lower for donors who earned the money, recipients who already had money, child or student donors, concealed or repeat donations, group decisions, donations to people in closer relationships, and donors forced to choose between keeping all and splitting 50:50.

Providing donors with more funds led to a proportionally smaller sized donation: $d=0.145,95 \%$ CI [0.022,

0.269]. The size of this difference appeared proportional to the stake: there was medium-large correlation between effect size and $\log$ difference in endowment $(r=0.411, p=.090$; sig. one-tailed test, $\mathrm{p}=0.045)$. Log difference was used because some endowments were slightly bigger, and others were up to 1000 times bigger.

Door in the face / 'request then retreat': Making a large, objectionable request followed by a smaller, more reasonable request 


\begin{tabular}{|c|c|c|c|c|}
\hline Category / Review & $\begin{array}{l}\text { Included } \\
\text { in meta- } \\
\text { meta- } \\
\text { analysis }\end{array}$ & $\begin{array}{l}\text { Number } \\
\text { of studies } \\
\quad(\mathrm{K})\end{array}$ & $\begin{array}{l}\text { Number of } \\
\text { participants } \\
\quad(\mathrm{N})\end{array}$ & Summary of Results \\
\hline Feeley et al., 2012 & $\mathrm{Y}$ & 22 & NR & $\begin{array}{l}\text { When request was monetary, as opposed to research/volunteering/health, the door-in-the-face had a small, non- } \\
\text { significant increase in the case of both verbal incidence ("I will donate"; weighted mean difference }=0.153 \text { ) and } \\
\text { behavioural incidence (actual donations; weighted mean difference }=.116 \text { ). For other behaviours (e.g., } \\
\text { volunteering), it had a small positive effect on verbal behaviour only. }\end{array}$ \\
\hline
\end{tabular}

Promoting intuition instead of deliberation: Encouraging or forcing people to use their 'fast' thinking system by, for example, taxing their cognitive load

Y $60 \quad 12,574$

Fromell et al., 2020

N $\quad 22 \quad 4336$

Rand et al., 2016

$\mathrm{N}$

3

1831

Promoting intuition had no effect on donation incidence ( $g=-0.015,95 \%$ CI [-.07, 0.04]). Authors argue that, in most cases, intuitive and deliberate decisions do not conflict. Alternatively, dual-process models do not apply to donations.

Promoting intuition among women increased donation incidence ( 4 percentage points), but not men.

There was a significant gender $\mathrm{x}$ sex-role $\mathrm{x}$ cognitive processing interaction. For women who identified as masculine, deliberative processing reduced donation incidence. For women who identified as feminine, deliberative process did not influence incidence. Gender roles did not influence incidence for men.

Prosocial modelling: Seeing someone else donate (i.e., model the intended behaviour)

Prosocial modelling increased donation incidence ('material help'): $\mathrm{g}=.46,95 \% \mathrm{CI}[.36, .57]$ and non-material prosocial behaviour. Effect on incidence was stronger if prosocial model was rewarded, if study was published, or if study was in Europe/Asia. Effects were robust to many tests of publication bias.

Pique: asking for strange amounts of money (e.g., 17c) instead of typical denomination (e.g., 10c, \$1)

Lee \& Feeley, 2017

$\mathrm{Y}$

17

2,136

Pique technique increased donation incidence $(r=.27,95 \%$ CI $[.19, .34])$. No effect on donation size $(\mathrm{p}=.103)$, therefore total donations were much higher using pique $(r=.49)$. Effects were stronger when a reason for the odd number was also provided. Pique technique appears to disrupt typical refusal script

Tax deductibility: when government makes donations to a cause tax deductible

Peloza \& Steel, 2005

$\mathrm{N}$

$138 \quad 1,418,212$

A $\$ 1$ reduction in the cost of giving (i.e., via increased tax deductibility) increases total donation (incidence $\mathrm{x}$ size) by $\$ 1.44$, meaning tax deductions are 'treasury efficient.'

Moderators of donation-based crowdfunding: factors that appear to increase or decrease crowdfunding (e.g., GoFundMe)

Salido-Andres et al., 2020
N $\quad 92 \quad$ NR

Donation-based crowdfunding incidence and size is increased by a likeminded sense of community, a persuasive message (e.g., compelling or emotive imagery; value alignment), an easy interface, high donor privacy, 
campaigner expertise, a social media profile, and large social networks. Increasing engagement and empowerment of donors appears to help, as does promoter transparency.

Gain-framed messages: for example, 'save a child' rather than 'a child will go to bed hungry'

\begin{tabular}{|c|c|c|c|c|}
\hline Xu \& Huang, 2020 & $\mathrm{Y}$ & 25 & 5811 & No effect of gain-framed messages on donation incidence $(r=-.006, p=.90)$. No moderation by age, gender, \\
\hline
\end{tabular}




\section{Meta-meta-analysis of interventions on donation size and donation incidence}

As shown in Figure 2, the meta-meta-analytic pooled effect on donation size and donation incidence was small $(r=0.08,95 \% \mathrm{CI}[0.03,0.12], K=23)$. The pooled effect was calculated using meta-analyses reported in the included systematic reviews. These effects were heterogeneous between reviews $\left(I_{2}^{2}=0.85\right)$, meaning that the different interventions (e.g., pique, identifying recipient) had very different effects on outcomes (e.g., donation size). The effects were not moderated by the specific outcome $(p=.12)$. As seen in Figure 2, this means pooled effects were similar for donation incidence $(r=0.15,95 \%$ CI $[0.05,0.25], K=4)$ and donation

size $(r=0.06,95 \%$ CI $[0.02,0.11], K=19)$. Raw effect sizes extracted from meta-analyses in the included reviews are available on the Open Science Framework (https://osf.io/465ej/?view_only=8f0ed79442cc4bc59feeb8d0880c6698). 


\section{Figure 2}

Pooled Effect Sizes and 95\% Confidence Intervals from Meta-analyses of Interventions, Grouped by Outcome (Donation Size vs. Incidence)

Pique (asking for strange amounts of money: 17c) Prosocial modelling Observability (real and artificial) Increase the perceived neediness of recipient Describing an identifiable victim Identify the donor to the recipient Match (or supplement) donor contributions Allow donation amount to be concealed Repeated opportunities to donate Adding uncertainty to the benefit Conceal both donation amount and donor identity Provide cue that the donor is being observed Gain-framed message

$$
\text { Forcing intuition }
$$

Higher stakes (larger pot to donate from) Decision made by a group

Limiting the number of donation options Legitimizing paltry contributions Pooled Effect Size

Pique (asking for strange amounts of money: 17c) Door in the face

Provide cue that the donor is being observed Legitimizing paltry contributions

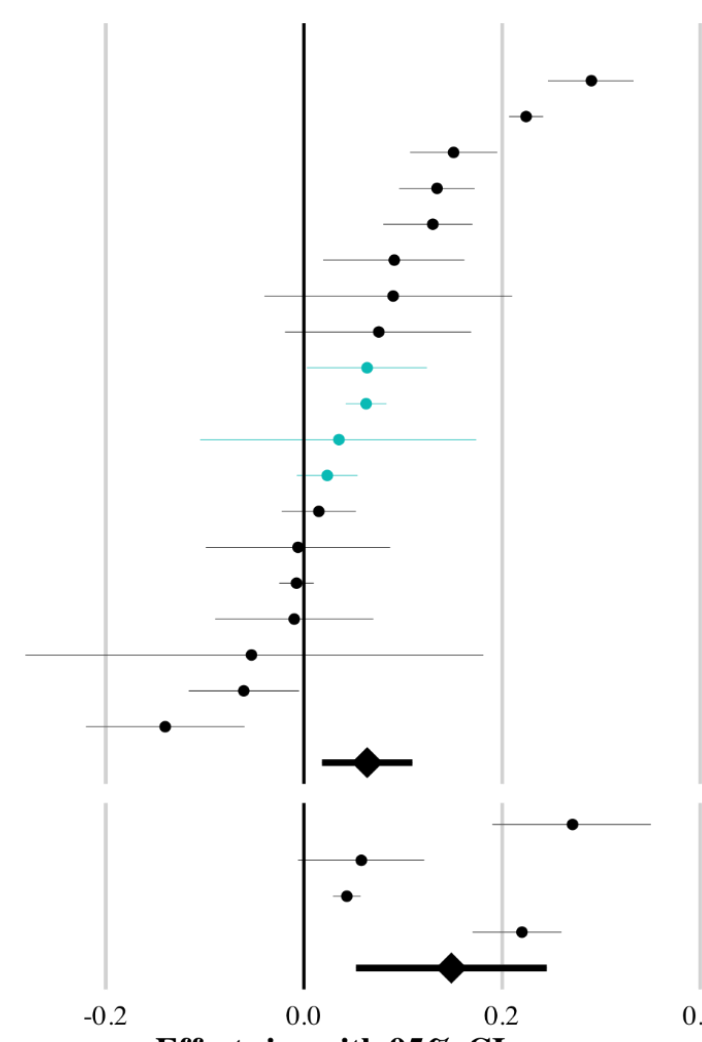

\begin{tabular}{c|c|l}
\hline $\mathbf{r}[\mathbf{9 5 \%} \mathbf{C I}]$ & $\mathbf{k}$ & Citation \\
$0.29[0.25,0.33]$ & 16 & Lee \& Feeley, 2017 \\
$0.22[0.21,0.24]$ & 40 & Jung et al, 2020 \\
$0.15[0.11,0.20]$ & 101 & Bradley et al., 2018 \\
$0.13[0.10,0.17]$ & 69 & Engel, 2011 \\
$0.13[0.08,0.17]$ & 47 & Butts et al., 2019 \\
$0.09[0.02,0.16]$ & 52 & Engel, 2011 \\
$0.09[-0.04,0.21]$ & 9 & Coyne et al., 2018 \\
$0.08[-0.02,0.17]$ & 18 & Engel, 2011 \\
\hline $0.06[0.00,0.12]$ & 19 & Engel, 2011 \\
$0.06[0.04,0.08]$ & 64 & Engel, 2011 \\
$0.04[-0.10,0.17]$ & 7 & Engel, 2011 \\
$0.02[-0.01,0.05]$ & 118 & Engel, 2011 \\
$0.01[-0.02,0.05]$ & 26 & Northover et al., 2017 \\
$-0.01[-0.10,0.09]$ & 25 & Xu \& Huang, 2020 \\
\hline$-0.01[-0.02,0.01]$ & 60 & Fromell et al., 2020 \\
$-0.01[-0.09,0.07]$ & 603 & Engel, 2011 \\
$-0.05[-0.28,0.18]$ & 4 & Engel, 2011 \\
$-0.06[-0.12,0.00]$ & 31 & Engel, 2011 \\
$-0.14[-0.22,-0.06]$ & 14 & Lee et al., 2016 \\
\hline $0.06[0.02,0.11]$ & & \\
\hline & & \\
\hline $0.27[0.19,0.35]$ & 16 & Lee \& Feeley, 2017 \\
$0.06[-0.01,0.12]$ & 15 & Feeley et al., 2012 \\
\hline $0.04[0.03,0.06]$ & 27 & Northover et al., 2017 \\
$0.22[0.17,0.26]$ & 34 & Bolkan \& Rains, 2017 \\
$0.15[0.05,0.25]$ & & \\
\hline & &
\end{tabular}

Effect size with $95 \%$ CI

Note. All effect sizes were converted to $r$, allowing for more meaningful comparisons between reviews. Light rows were interventions

hypothesised to reduce donations. For these interventions, the sign of effects were reversed during analyses to calculate meaningful meta-meta-analytic pooled effect sizes. 


\section{Interventions to increase charitable donations organised using Bekkers and Wiepking's (2011) model}

We used a mixed-methods approach to synthesise quantitative effect size estimates with a qualitative analysis of findings according to Bekkers and Wiepking (2011b), with descriptions of each included review. We conducted a further meta-meta-analysis (Figure 3) with interventions grouped by the mechanism ascribed by Bekkers and Wiepking (2011b). As shown in Figure 3, the pooled effects of each hypothesised mechanism was significant, however there was large heterogeneity in the effects of each mechanism (all $I^{2}$ total $>0.70$ ). Moderation analyses for interventions within each mechanism were all significant (each $p<.018$ ), suggesting that the specific design, channel, or context in which the intervention was delivered influenced the effective use of the hypothesised mechanism. In the following sections, we describe each identified behaviour change intervention organised by mechanism. 


\section{Figure 3}

Pooled Effect of Donation Size (with 95\% Confidence Intervals) from Meta-analyses of Interventions, Grouped by Hypothesised Mechanism

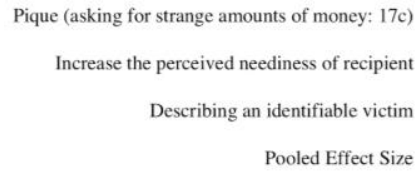

Forcing intuition

Limiting the number of donation options

Pooled Effect Size
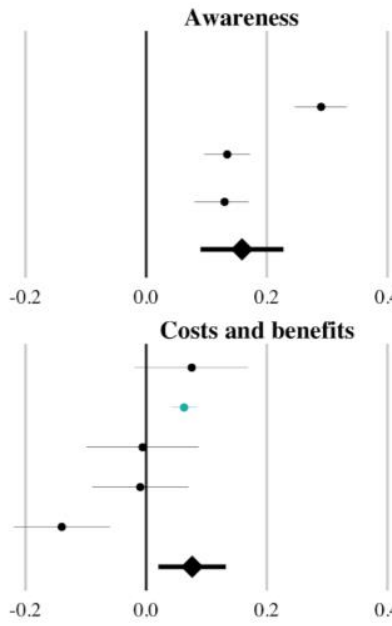

$$
\text { Efficacy }
$$
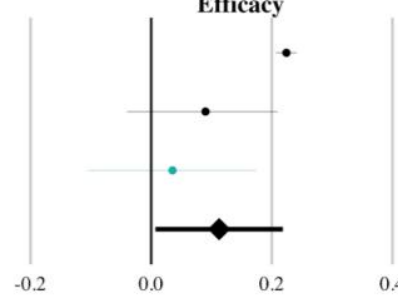

$0.22[0.21,0.24] \quad 40 \quad$ Jung et al, 2020

$0.09[-0.04,0.21] \quad 9 \quad$ Coyne et al.., 2018

$0.04[-0.10,0.17] \quad 7 \quad$ Engel. 2011

$0.11[0.01,0.22]$

$0.15[0.11,0.20] 101 \quad$ Bradley et al., 2018

$0.09[0.02,0.16] \quad 52 \quad$ Engel, 2011

$0.06\{0.00,0.12 \mid \quad 19 \quad$ Enget, 2011

$0.02\{-0.01,0.05\} \quad 118 \quad$ Engel, 2011

$0.01[-0.02,0.05] \quad 26 \quad$ Northover et al., 2017

$-0.05[-0.28,0.18] \quad 4 \quad$ Engel, 2011

$0.06[0.00,0.12]$

$-0.01[-0.02,0.01] \quad 60 \quad$ Fromell et al., 2020

$-0.06[-0.12,0.00] \quad 31 \quad$ Engel, 201$\}$

$-0.04[-0.12,0.04]$

Note. All effect sizes were converted to $r$ to allow for meaningful comparisons between reviews.

Light rows were interventions hypothesised to reduce donations. For these interventions, the sign of effects were reversed during analyses to calculate meaningful pooled effect sizes. 


\section{Interventions to Increase Awareness}

On average, strategies designed to increase awareness ${ }^{1}$ had small to moderate effects on donations $(r=0.16,95 \% \mathrm{CI}[0.09,0.23], K=3)$. In general, charities can increase awareness and therefore donations by piquing donor interest, demonstrating the need, or identifying a victim.

There were large effects from the pique technique. Piquing interest increased both compliance $(r=0.27,95 \%$ CI $[0.19,0.35], k=16$; Lee \& Feeley, 2017) and donation size $(r=$ $0.29,95 \% \mathrm{CI}[0.25,0.33], k=16$; Lee $\&$ Feeley, 2017), leading to much larger total revenue ( $r=$ $0.49,95 \%$ CI $[0.45,0.53], k=16$; Lee $\&$ Feeley, 2017). The pique technique involved asking donors for unusual amounts of money (17c instead of $10 \mathrm{c})$, and was designed to break the 'refusal script': would-be donors were more likely to stop and ask for a rationale when an odd amount of money was requested of them (Lee \& Feeley, 2017). The largest experiment involved a $\$ 3$ request so the technique may have questionable ecological validity. It is unclear whether it would also work for requesting $\$ 1,017$ instead of $\$ 1,000$.

Describing a needy recipient increased donations. This was evaluated in three metaanalyses. Engel found that needy recipients received an increased donation size in dictator games $\left(r=0.13,95 \%\right.$ CI $[0.10,0.17], k=69 ;$ Engel, 2011) ${ }^{2}$ Neediness was also a mechanism that explained legitimizing paltry contributions (described below). When someone said "even a penny would help", many donors saw the recipient as more needy, which had indirect effects on donation compliance (Bolkan \& Rains, 2017). Finally, compared with causes with modest negative impact (e.g., no school books), when a problem was described as severe, certain, and

\footnotetext{
${ }^{1}$ We expect 'compassion face' could be categorized under a number of different mechanisms, but relied on Bekkers and Wiepking (2011) who explicitly identified this as 'awareness'.

2 Dictator games are designed as contrived analogies for donation situations: one participant is given some money and is given the chance to donate to another with no consequences or tangible benefits. Since actual money changes hands to a relative stranger, we deemed it sufficiently analogous to real charitable donations for this review.
} 
calamitous (e.g., natural disaster), donation size increased regardless of whether the victim was identifiable or not (Butts et al., 2019).

Describing an identifiable victim increased donation size. Under most circumstances, donation size increased when donors were presented with a single, 'identifiable victim' $(r=0.13$, 95\% CI [0.08, 0.17], $k=47$; Butts et al., 2019) than when presented with statistics or multiple recipients. This is also known as 'compassion fade', where a larger number of victims leads to lower perceived impact and lower expected positive affect from donating (Jenni \& Loewenstein, 1997). Mediation analyses supported these hypothesised paths (Butts et al., 2019). Empathy had a smaller mediating role: while people showed slightly less empathy for a larger group of people, this lower empathy had only a small effect on donations.

\section{Interventions to Reduce Cost or Increase Benefits}

On average, strategies targeting costs and benefits weakly increased donations $(r=0.08$, 95\% CI [0.02, 0.13], $K=5)$. The most influential effects appeared to be imbuing a charity with tax deductibility, but nudges or framing strategies had few effects.

Tax Deductibility Increased Donations. One large meta-analysis of 69 studies $(n=$ $1,418,212$ ), examined the impact of tax deductibility on charitable donations (Peloza \& Steel, 2005). Effects were reported as price elasticities which could not be converted to effect sizes. They found substantial elasticity: a tax deduction of $\$ 1$ resulted in an additional $\$ 1.44$ being donated to charity (confidence interval not reported). The authors found that tax deductions particularly increased the likelihood of bequests. High income donors were no more concerned with tax deductions than lower income donors.

\section{Matching (or Supplementing) Donor Contributions did not Affect Donations. In}

contrived experiments, when donors were told their funds would be matched (fully or partially), 
there was a small but non-significant increase in donations $(r=0.08,95 \% \mathrm{CI}[-0.02,0.17], k=$ 18; Engel, 2011).

'Door-in-the-Face' Does not Reliably Increase Donations. Door in the face is designed to reduce the perceived cost of donating by initially presenting a high anchor (e.g., "will you donate $\$ 1000$ ?"), then asking for something more achievable (e.g., "how about $\$ 10$ ?”; also known as the 'request then retreat strategy'). Evidence for this strategy appears weak: donors may be marginally more likely to say they will donate $(r=0.08,95 \%$ CI $[0.03,0.12], k=7$; Feeley et al., 2012) but this does not translate into actual compliance ( $r=0.06,95 \%$ CI [-0.01, 0.12], $k=15$; Feeley et al., 2012).

Repeated Opportunities/Requirements to Donate Decreased Donations. In contrived experiments with repeated rounds, donors gave less when they were aware there would be multiple opportunities to donate $(r=-0.06,95 \%$ CI [-0.08, -0.04], $k=64$; Engel, 2011).

Gain-Framed Messaging did not Affect Donations. Prospect theory proposes that small losses loom larger than small gains, but framing appeals for charitable donations as 'losses averted' did not increase the likelihood of donations $(r=-0.01,95 \%$ CI $[-0.10,0.09], k=25 ; \mathrm{Xu}$ \& Huang, 2020).

Higher Stakes Inconsistently Decreased Donations. Some studies have asked whether those donating from larger pools of money (usually in contrived experiments) are more generous or more frugal. The larger of the two meta-analyses found no relationship between stake size and donations $(r=-0.01,95 \%$ CI [-0.09, 0.07], $k=603$; Engel, 2011). But, a follow-up, more focused meta-analysis found that those endowed with more money tended to be less generous, in relative terms, than those endowed with less $(r=-0.07,95 \%$ CI $[-0.03,-0.12], k=18$; Larney et 
al., 2019). That is, when people had more, they may donate more in absolute terms, but usually donated a lower percentage of the money they held.

Legitimizing Paltry Contributions has Negligible Total Benefit. Three systematic reviews investigated the effect of 'legitimising paltry contributions' on charitable donations (usu. words like "even a penny will help"; Andrews et al., 2008; Bolkan \& Rains, 2017; Lee et al., 2016). The largest of these reviews found a moderate increase in compliance $(r=0.22,95 \% \mathrm{CI}$ $[0.17,0.26], k=34$; Bolkan \& Rains, 2017) which was offset by a decrease in the size of the average donation $(r=-0.23,95 \% \mathrm{CI}[-0.34,-0.12], k=11$; Bolkan \& Rains, 2017). The net effect of these competing forces was a non-significant increase in total revenue $(r=0.03,95 \% \mathrm{CI}$ $[-0.01,0.07], k=18$; Bolkan \& Rains, 2017). Mediation analyses suggest that the technique increases the perceived neediness of the cause, but that it also vindicates those likely to donate a small amount to avoid judgement (i.e., donors high on 'impression management').

\section{Interventions to Increase Efficacy}

On average, strategies targeting efficacy increased donations $(r=0.11,95 \% \mathrm{CI}[0.01$, 0.22 ], $K=3$ ). Direct modelling of the desired behaviour — seeing others donate money—appears to increase donations, but general prosocial media does not.

Prosocial Modelling Moderately Increased Donations, Regardless of Media. When people saw others acting prosocially, they were more likely to imitate, including for charitable donations ( $r=0.22,95 \%$ CI [0.21, 0.24], $k=40$; Jung et al, 2020). Effects were consistent across media (e.g., direct observation vs watching on TV), age, gender, and culture.

Generic Prosocial Media has Uncertain Effects. Jung and colleagues (2020) looked at studies where the model performed the same behaviour (i.e., the model donated money and the dependent variable was donation too); they moderated for how the model was viewed (real 
observation vs. via media). Coyne and colleagues (2018) instead looked at media only (TV, movies, video games, music or music videos) with explicitly prosocial content (but not necessarily donating money). Participants in one study were more likely to donate money while listening to "Love generation" (by Bob Sinclair) rather than "Rock this party" (also Bob Sinclair; Greitemeyer, 2009). This trend, however, was not reliable with small pooled effects on financial donations and a confidence interval including the null hypothesis $(r=0.09,95 \%$ CI [-0.04, 0.21], $k=9$; Coyne et al., 2018). The media seldom demonstrated the exact behaviour being measured (i.e., 'Love generation' does not talk about donations); imitation and efficacy may increase the likelihood of the behaviour being observed but effects do not spill over to nearby prosocial behaviours.

\section{Certainty of Donation Benefit has Little Influence on Donation Compliance. As}

mentioned previously, correlational studies show that certain calamities appear to attract donations, regardless of interventions like 'identifiable victims' (Butts et al., 2019). Among dictator games, when uncertainty was added to the benefit (e.g., donating lottery tickets) there was no significant reduction in donations ( $r=-0.04,95 \%$ CI $[-0.17,0.10], k=7$; Engel, 2011). This may not necessarily translate to different types of uncertainty, however, such as uncertainty that a charity will have an impact.

\section{Interventions to Increase Reputation}

On average, strategies targeting reputation slightly increased donations $(r=0.06,95 \% \mathrm{CI}$ $[0.00,0.12], K=6)$. In general, people are somewhat more likely to donate when there is some reputational benefit of doing so (e.g., being observed or having the donation amount visible).

Being Observed by Others Increases Donations. After synthesising a large number of studies and participants $(N>500,000)$, Bradley and colleagues found that being observed 
significantly increased donations ( $r=0.15,95 \%$ CI [0.11, 0.20], $k=101$; Bradley et al., 2018).

Consistent with reputation hypotheses, effects were larger for repeat interactions, interactions with personal consequences, group social dilemmas (vs. 1:1 bargaining games), and where observation is more intense. In contrast, Engel moderated his findings by whether or not donations were concealed. He found donations decreased when concealing the donor $(r=-0.09$, 95\% CI [-0.02, -0.16], $k=52$; Engel, 2011) or the amount donated $(r=-0.06,95 \%$ CI [-0.12, 0.00], $k=19$; Engel, 2011), but effects were small.

Artificial Cues of Being Observed Do Not Reliably Increase Donations. Three systematic reviews have explored the effect of artificial surveillance cues on donor generosity (Sparks \& Barclay, 2013; Nettle et al., 2013; Northover et al 2017). Studies have typically analysed the effect of displaying images of 'watching eyes' on donation decisions made within economic games, but many include field experiments (e.g., eyes above 'honesty boxes'). The largest of these reviews found negligible increases in compliance $(r=0.04,95 \%$ CI [0.03, 0.06], $k=27$; Northover et al., 2017) and donation size $(r=0.01,95 \%$ CI $[-0.02,0.05], k=26$;

Northover et al., 2017). Effects seem to only work short-term, with few studies finding any longterm benefits (Sparks \& Barclay, 2013). Overall, artificial surveillance may increase the chance of people donating something in the short term, but the best quality evidence suggests effects are small.

Decision made by a group. Making a decision as a group may increase the reputational stakes of signalling altruism but also may diffuse the reputational benefit of donating. Group decisions had no significant total influence on donations $(r=-0.05,95 \%$ CI $[-0.28,0.18], k=4$; Engel, 2011) but the confidence intervals are wide due to the small number of studies. 


\section{Interventions to Affect Altruism}

Few reviews explored the altruism mechanism proposed by Bekkers and Wiepking (2011b). Two reviews explored the crowding out hypothesis - that donors motivated by a desire to have an impact would avoid causes already supported by governments because of diminishing marginal returns (Lu, 2016, $k=60$; de Wit and Bekkers, 2017, $k=54)$. Neither review found decisive evidence for crowding out. A subset of the studies in the reviews had higher internal validity - they either controlled for confounding statistically or via experimental designs. These studies were more likely to suggest that government funding reduces private donations (de Wit \& Bekkers, 2017; Lu, 2016), but given the small, heterogeneous effect sizes, the evidence for a relationship is weak.

\section{Other Influences That Have Been Explored}

We did not find reviews of interventions that could be easily classified as 'solicitation', 'psychological benefits', or 'values'. We could not easily classify two review findings on the basis of Bekkers and Wiepking's (2011) mechanisms. One review tested a range of interventions designed to promote intuitive thinking (e.g., high cognitive load), but these studies did not influence donations ( $r=-0.01,95 \%$ CI [-0.02, 0.01], $k=60$; Fromell et al., 2020). The authors argue that 'fast' and 'slow' thinking are often aligned on issues of charitable donations. Engel (2011) found that reducing the number of options available to the donor decreased the amount they donated.

\section{Discussion}

Charities conduct activities that seek to address a wide range of social problems (MacAskill, 2015; Singer, 2019). Our meta-review identified interventions (e.g., piquing donor interest, prosocial modelling, increased neediness, identifiable victims, tax deductibility) that 
robustly increase charitable donation size or incidence. The effect size of most interventions on charitable donations were relatively small in terms of increasing the success of individual opportunities to donate $(|r|<0.1)$, but would likely "add up" over time (Funder \& Ozer, 2019). It is important to note that our certainty for this estimate is low, due to limitations in many of the included systematic reviews (e.g., many did not assess the quality of included studies; many neglected publication bias). Most effect sizes were far smaller than the average effect size of interventions in marketing science ( $r=.24$; Eisend, 2015; Eisend \& Tarrahi, 2016) or social psychology $(r=.21$; (Richard et al., 2003). We identified support for some of the mechanisms described in a widely-used model of charitable donations (increasing awareness, efficacy, benefits, and reputation; Bekkers \& Wiepking, 2011b) and some gaps in the review-level literature (e.g., systematic reviews assessing psychosocial benefits or values). Most reviews included primary studies that assessed interventions in contrived experiments, but some found consistent results in field and laboratory experiments. The findings suggest that several types of interventions can help to increase charitable donations, but the overall poor quality of the evidence suggests that expert judgement and contextual factors will be critical for good decisions in charity promotion.

\section{Practitioners May Draw From a Range of Robust Interventions to Increase Charitable}

\section{Donations}

Taking the findings together, and notwithstanding the limitations of the included reviews, we recommend practitioners consider the following interventions for promoting charitable donations. Examples of the source, recipient, context, channel, and content of each intervention (Lasswell, 1948; Slattery et al., 2020) is presented in Supplementary Table S3. 
Help Donors Feel Confident. When interventions increased donor confidence, they tended to solicit higher donations. Effective strategies included seeing other people who donated money (Jung et al., 2020), not merely seeing people performing 'prosocial behaviours' (Coyne et al., 2018). Theory and preliminary findings would suggest that effects are stronger when viewing those who share our group identity (Chapman et al., 2018, 2020). Uncertainty about the benefit of a charitable donation may cause prospective donors to reduce their donation size; donation matching campaigns may cause prospective donors to slightly increase their contribution (Engel, 2011). Identifiable victims work because donors feel more confident that they could make a meaningful difference (Butts et al., 2019). Overall, the key mechanism is that if prospective donors think they can make a meaningful difference, they are more likely to donate (Butts et al., 2019).

Provide Donors with Meaningful Rationales for Why Donations are Needed. Donors are persuaded by needy recipients (Engel, 2011). Campaigns that say things like 'even a penny will help' can increase the likelihood of an initial donation when it signals the 'desperate need' of the cause (Bolkan \& Rains, 2017). Similarly, highlighting a single beneficiary ("identifiable victim") does not change likelihood of donation behaviour if the charitable cause is obviously severe and widespread (Butts et al., 2019). Piquing a donor's interest via odd requests (e.g., 17c) appears to work by prompting a conversation around why the donation is needed (Lee \& Feeley, 2017).

Help Donors to Look Good in Front of Others, but Beware Side-Effects. Donations are more likely when donors are observed (Bradley et al., 2018), and when both they and their donation size are identified to recipients (Engel, 2011). Charities should be careful to avoid using this in a way that creates guilt or social pressure (Bennett, 1998) or in a way that is contrived/artificial (Northover et al., 2017; Sparks \& Barclay, 2013). Instead, charities can use transparency as a 
way of facilitating pride and self-efficacy (Crocker et al., 2017), to minimise the taboo around discussing charitable donations publicly, and to help establish a social norm toward giving (Singer, 2019).

Seek and Advertise Tax Deductibility. Given the large and significant price elasticity from tax deductibility (i.e., tax-deductibility increased donations; Peloza \& Steel, 2005), directing effort toward becoming tax deductible will likely pay dividends. While few studies explicitly assessed the impact of advertising deductibility, we assume that doing so may confer some benefits for donations.

\section{Some 'Nudges' and Compliance Techniques Work but Have Modest Expectations. Nudges}

usually assume that people will be more likely to donate if charities activate their 'fast', intuitive thinking system, but this is not the case (Fromell et al., 2020). It appears that intuitive and deliberate thinking around donations are usually aligned. Nudges and framing strategies such as artificial cues (Northover et al., 2017; Sparks \& Barclay, 2013), legitimizing paltry contributions (Bolkan \& Rains, 2017), 'door-in-the-face', (Feeley et al., 2012) are not consistently effective.

\section{To Aid Evidence-Informed Decision-Making, Reviews and Research Must Improve}

Despite being mostly systematic reviews of randomised trials — which are the best causal evidence for effects of interventions (see Figure 1) —we judged the certainty of all effects to be low. This was because the reviews here, and their included studies, often failed many well established criteria for internal and external validity (Guyatt et al., 2011; Higgins et al., 2019; Hultcrantz et al., 2017). Many interventions were only tested in laboratories or in experiments with relatively trivial amounts of money $(<\$ 10)$. In contrast, many methods of persuasion commonly used in charitable contexts, such as emotional appeals and rational arguments (Bennett, 2019; Caviola et al., 2020; Stannard-Stockton, 2009), were seldom examined directly 
by the reviews we found. In addition to reviewing more authentic interventions, review authors could increase the reliability and transparency of their methods via AMSTAR 2 and PRISMA. Registration and standardised reporting checklists like PRISMA (Moher et al., 2010; Page et al., 2021) improve the internal validity of systematic reviews through common expectations of methodology and reporting.

\section{Results Supported Many Mechanisms Proposed by Bekkers and Wiepking (2011)}

Many interventions designed to increase awareness, efficacy, and reputation appeared to usually increase donations, as hypothesised by (Bekkers \& Wiepking, 2011b).We did not find systematic reviews that assessed other hypothesised mechanisms as classified by Bekkers and Wiepking (2011b), such as solicitation, psychological benefits, and values. However, these findings may not necessarily reflect strengths and weaknesses in the proposed mechanisms, but could reflect the way interventions are categorised. As described above, we followed the categorisation of Bekkers and Wiepking (e.g., identifiable victim as 'awareness') even if we had reason to think that interventions may be better classified elsewhere (i.e., identifiable victim as 'efficacy' or 'psychological benefits'; Butts et al., 2019). Primary studies and non-systematic reviews have found support for some other mechanisms (psychological benefits, Crocker et al., 2017; value alignment, Goenka \& van Osselaer, 2019) but for formal model building, researchers should explicitly test whether interventions are operating by the hypothesised mechanism.

\section{Limitations Of Our Meta-Review}

By focusing on review-level evidence we necessarily excluded primary studies that would have been useful for charity and non-profit researchers and practitioners. While a review of the 1,339 included primary studies would have been intractable, reviews of primary studies have sufficient granularity to look at mediators and moderators that might be useful across 
studies. Instead, we were beholden to the methods of the included reviews. Similarly, we were limited to the interventions selected by previous reviewers, so necessarily omitted interventions not included in any systematic reviews, even though they may inform research and practice (e.g., opt-in vs. opt-out donations; Everett et al., 2015). There may, for example, be a wealth of knowledge on interventions using the internet to drive donations, but since there have been few systematic reviews on that topic, those interventions would have been excluded from our metareview (Bennett, 2016, 2019; Liang et al., 2014). In a similar vein, focusing on systematic reviews means we may have excluded some more recent, 'cutting-edge' interventions. It often takes a number of years between an intervention gaining traction and it being subject of a systematic review. For example, recent research has shown that donors may actually prefer costeffectiveness indicators (i.e., cost per life saved) to overhead ratios (i.e., percent directed to administrative expenses) but that the latter is usually the focus of decision-making because of the 'evaluability bias': people weigh an attribute based on how easy it is to evaluate (Caviola et al., 2014). However, few studies have examined the effect of publishing cost-effectiveness indicators so it is not yet possible to meta-analyse these interventions. As a result, while the interventions presented in our review have been thoroughly assessed, and many have been shown to be robustly beneficial, there may be other interventions with larger effect sizes not listed here.

Our meta-review prospectively excluded grey literature and reviews in other languages. This may affect generalisability, but doing so seldom affects conclusions from meta-reviews (unlike reviews of primary studies; Ganann et al., 2010), and we excluded no reviews on the basis of this criteria (see Figure 1). This is likely because unpublished reviews of charitable donations are less likely to use systematic search and synthesis methods. Nevertheless, there may 
be other reviews that contribute to this discussion that were missed by our searches and inclusion criteria.

Our review used well validated assessments of certainty (i.e., GRADE) and review quality (i.e., an abbreviated AMSTAR2 checklist; see Supplementary File 1). These assessments allow interested readers to know the quality of the included reviews and certainty of the included findings. However, in a meta-review, these tools are again beholden to the methods of the included systematic reviews. For example, GRADE reduces the certainty of the findings if there are few randomised experiments, or if the included randomised experiments may have been subject to common experimental biases (e.g., if they were unblinded). These biases reduce the internal validity of the findings, but few included reviews formally assessed these biases. As a result, we could not conduct sophisticated assessments of the internal validity of the included without examining the methods of the 1,339 primary studies. We hope future systematic reviews of primary studies more frequently assess these biases using a validated tool, like ROB2 (Sterne et al., 2019). Similarly, GRADE accounts for the external validity of the included studies—such as whether or not findings are likely to generalise to the populations or situations most practitioners are interested in. This can be a complex question requiring judgement. For example, in some cases Mechanical Turk contractors may be representative samples, but external validity also depends on the design of the study (e.g., viewing a real advertisement vs. playing an economic game). Our ability to assess external validity was subject to the quality of the reporting in the included systematic reviews (unless we wanted to review all 1,339 methods). We hope future reviews discuss the external validity of their included studies, and could consider integrating those judgements into their own certainty assessment (e.g., via GRADE). Another 
approach would be to assess the facilitators and barriers of successfully delivering a pilot-tested intervention to new populations and in new contexts (e.g., scale up; Saeri et al., 2021)..

One additional limitation concerns the intervention of tax deductibility (Peloza \& Steel, 2005). This systematic review and meta-analysis investigated the impact of tax deductibility on charitable donations primarily in the United States, with a minority of included primary studies describing the effect in similar countries such as Canada and the United Kingdom. Given that formal tax structures and cultural values of taxation and charitable giving differ significantly between countries, and tax policy can vary over time within a given country, the substantial effect size observed in Peloza and Steel's (2005) meta-analysis may not hold in other settings.

\section{Conclusion}

Increasing charitable donations could benefit society in a multitude of ways: from helping to address global poverty, health, animal suffering, climate change, human rights, and the longterm future of humanity. As a result, identifying robust strategies for promoting charitable causes can have widespread social benefits. Providing good review-level evidence is a key way that charity science can contribute to evidence-informed decision-making in this important area.

In this meta-review, we synthesised multidisciplinary literature on how to promote charitable donations. We identified a range of strategies that may increase donations and some mechanisms that may help explain their effects. These findings suggest that organisations can solicit more money by focusing on individual victims, increasing the publicity of donations, discussing the impact of the donation, and both ensuring and promoting the tax-deductibility of their charity.

Future reviews into other interventions - particularly those conducted outside of contrived experimental settings - would allow researchers and practitioners to assess the 
ecological validity of those interventions. Readers could have more faith in those reviews if they more consistently followed best-practice approaches to systematic reviews. Our meta-review reveals patterns and gaps within the current research, but it also identifies an array of well researched mechanisms for promoting charitable donations. Using the findings of these reviews may increase the funds directed to some of the most important and neglected problems facing humanity. 


\section{References}

Andrews, K. R., Carpenter, C. J., Shaw, A. S., \& Boster, F. J. (2008). The legitimization of paltry favors effect: A review and meta-analysis. Communication Reports, 21(2), 59-69. https://doi.org/10.1080/08934210802305028

Assmus, G., Farley, J. U., \& Lehmann, D. R. (1984). How advertising affects sales: Meta-analysis of econometric results. Journal of Marketing Research, 21(1), 65-74. https://doi.org/10.2307/3151793

Becker, L. A., \& Oxman, A. D. (2011). Overviews of reviews. In J. P. T. Higgins \& S. Green (Eds.), Cochrane Handbook for Systematic Reviews of Interventions (Version 5.1.0). The Cochrane Collaboration. https://handbook-5-1.cochrane.org/chapter_22/22_overviews_of_reviews.htm

Bekkers, R., \& Wiepking, P. (2011a). Who gives? A literature review of predictors of charitable giving Part One: Religion, education, age and socialisation. Voluntary Sector Review, 2(3), 337-365. https://doi.org/10.1332/204080511X6087712

Bekkers, R., \& Wiepking, P. (2011b). A Literature Review of Empirical Studies of Philanthropy: Eight Mechanisms That Drive Charitable Giving. Nonprofit and Voluntary Sector Quarterly, 40(5), 924973. https://doi.org/10.1177/0899764010380927

Bendapudi, N., Singh, S. N., \& Bendapudi, V. (1996). Enhancing Helping Behavior: An Integrative Framework for Promotion Planning. Journal of Marketing, 60(3), 33-49. https://doi.org/10.1177/002224299606000303

Bennett, R. (1998). Shame, guilt \& responses to non-profit \& public sector ads. International Journal of Advertising, 17(4), 483-499. https://doi.org/10.1080/02650487.1998.11104734

Bennett, R. (2019). Nonprofit marketing and fundraising: a research overview. Routledge. https://content.taylorfrancis.com/books/download?dac=C2017-0-674480\&isbn=9781351055093\&format=googlePreviewPdf

Blinded for review. (2019, July 14). Philanthropy and charitable giving: A review of reviews. https://osf.io/465ej/?view_only=8f0ed79442cc4bc59feeb8d0880c6698 
Bolkan, S., \& Rains, S. A. (2017). The Legitimization of Paltry Contributions as a Compliance-Gaining Technique: A Meta-Analysis Testing Three Explanations. Communication Research, 44(7), 976996. https://doi.org/10.1177/0093650215602308

Bradley, A., Lawrence, C., \& Ferguson, E. (2018). Does observability affect prosociality? Proceedings. Biological Sciences / The Royal Society, 285(1875). https://doi.org/10.1098/rspb.2018.0116

Butts, M. M., Lunt, D. C., Freling, T. L., \& Gabriel, A. S. (2019). Helping one or helping many? A theoretical integration and meta-analytic review of the compassion fade literature. Organizational Behavior and Human Decision Processes, 151, 16-33. https://doi.org/10.1016/j.obhdp.2018.12.006

Caviola, L., Faulmüller, N., Everett, J. A. C., Savulescu, J., \& Kahane, G. (2014). The evaluability bias in charitable giving: Saving administration costs or saving lives? Judgment and Decision Making, 9(4), 303-316. https://www.ncbi.nlm.nih.gov/pubmed/25279024

Caviola, L., Schubert, S., Teperman, E., Moss, D., Greenberg, S., \& Faber, N. S. (2020). Donors vastly underestimate differences in charities' effectiveness. Judgment and Decision Making, 15(4), 509516. http://journal.sjdm.org/20/200504/jdm200504.pdf

Chapman, C. M., Louis, W. R., \& Masser, B. M. (2018). Identifying (our) donors: Toward a social psychological understanding of charity selection in Australia. Psychology \& Marketing, 35(12), 980989. https://doi.org/10.1002/mar.21150

Chapman, C. M., Masser, B. M., \& Louis, W. R. (2020). Identity motives in charitable giving: Explanations for charity preferences from a global donor survey. Psychology \& Marketing, 37(9), 1277-1291. https://doi.org/10.1002/mar.21362

Charity Navigator. (2022). 10 Most Followed Charities. Charity Navigator. https://www.charitynavigator.org/index.cfm?bay=topten.detail\&listid=148

Cheung, M. W.-L. (2014). metaSEM: an R package for meta-analysis using structural equation modeling. Frontiers in Psychology, 5, 1521. https://doi.org/10.3389/fpsyg.2014.01521

Conigrave, J. (2019). msemtools: Routines, tables, and figures for metaSEM analyses (Version 0.9.8) 
[Computer software]. Github. https://github.com/JConigrave/msemtools

Coyne, S. M., Padilla-Walker, L. M., Holmgren, H. G., Davis, E. J., Collier, K. M., Memmott-Elison, M. K., \& Hawkins, A. J. (2018). A meta-analysis of prosocial media on prosocial behavior, aggression, and empathic concern: A multidimensional approach. Developmental Psychology, 54(2), 331-347. https://doi.org/10.1037/dev0000412

Crocker, J., Canevello, A., \& Brown, A. A. (2017). Social Motivation: Costs and Benefits of Selfishness and Otherishness. Annual Review of Psychology, 68, 299-325. https://doi.org/10.1146/annurevpsych-010416-044145

Del Re, A. C. (2020). Package “compute.es”: Compute Effect Sizes (Version 0.2-5) [Computer software]. https://cran.r-project.org/web/packages/compute.es/compute.es.pdf

de Wit, A., \& Bekkers, R. (2017). Government support and charitable donations: A meta-analysis of the crowding-out hypothesis. Journal of Public Administration Research and Theory, 27(2), 301-319. https://doi.org/10.1093/jopart/muw044

Engel, C. (2011). Dictator games: A meta study. Experimental Economics, 14(4), 583-610. https://doi.org/10.1007/s10683-011-9283-7

Everett, J. A. C., Caviola, L., Kahane, G., Savulescu, J., \& Faber, N. S. (2015). Doing good by doing nothing? The role of social norms in explaining default effects in altruistic contexts. European Journal of Social Psychology, 45(2), 230-241. https://doi.org/10.1002/ejsp.2080

Feeley, T. H., Anker, A. E., \& Aloe, A. M. (2012). The door-in-the-face persuasive message strategy: A meta-analysis of the first 35 years. Communication Monographs, 79(3), 316-343. https://doi.org/10.1080/03637751.2012.697631

Fromell, H., Nosenzo, D., \& Owens, T. (2020). Altruism, fast and slow? Evidence from a meta-analysis and a new experiment. Experimental Economics, 23(4), 979-1001. https://doi.org/10.1007/s10683020-09645-z

Funder, D. C., \& Ozer, D. J. (2019). Evaluating effect size in psychological research: Sense and nonsense. 
Advances in Methods and Practices in Psychological Science, 2(2), 156-168.

https://doi.org/10.1177/2515245919847202

Ganann, R., Ciliska, D., \& Thomas, H. (2010). Expediting systematic reviews: methods and implications of rapid reviews. Implementation Science, 5, 56. https://doi.org/10.1186/1748-5908-5-56

GiveWell. (2021). Our Top Charities. GiveWell. https://www.givewell.org/charities/top-charities

Goenka, S., \& van Osselaer, S. M. J. (2019). Charities can increase the effectiveness of donation appeals by using a morally congruent positive emotion. The Journal of Consumer Research, 46(4), 774-790. https://doi.org/10.1093/jcr/ucz012

Grant, M. J., \& Booth, A. (2009). A typology of reviews: an analysis of 14 review types and associated methodologies: A typology of reviews, Maria J. Grant \& Andrew Booth. Health Information and Libraries Journal, 26(2), 91-108. https://doi.org/10.1111/j.1471-1842.2009.00848.x

Greitemeyer, T. (2009). Effects of songs with prosocial lyrics on prosocial thoughts, affect, and behavior. Journal of Experimental Social Psychology, 45(1), 186-190.

https://doi.org/10.1016/j.jesp.2008.08.003

Guyatt, G. H., Oxman, A. D., Schünemann, H. J., Tugwell, P., \& Knottnerus, A. (2011). GRADE guidelines: A new series of articles in the Journal of Clinical Epidemiology. Journal of Clinical Epidemiology, 64(4), 380-382. https://doi.org/10.1016/j.jclinepi.2010.09.011

Hennessy, E. A., Johnson, B. T., \& Keenan, C. (2019). Best Practice Guidelines and Essential Methodological Steps to Conduct Rigorous and Systematic Meta-Reviews. Applied Psychology. Health and Well-Being, 11(3), 353-381. https://doi.org/10.1111/aphw.12169

Higgins, J. P. T., Altman, D. G., Sterne, J. A. C., \& on behalf of the Cochrane Statistical Methods Group and the Cochrane Bias Methods Group. (2011). Assessing risk of bias in included studies. In J. P. T. Higgins \& S. Green (Eds.), Cochrane Handbook for Systematic Reviews of Interventions (Vol. 5.1.1). The Cochrane Collaboration.

Higgins, J. P. T., Thomas, J., Chandler, J., Cumpston, M., Li, T., Page, M. J., \& Welch, V. A. (2019). 
Cochrane Handbook for Systematic Reviews of Interventions. John Wiley \& Sons.

https://training.cochrane.org/cochrane-handbook-systematic-reviews-interventions

Hinde, S., \& Spackman, E. (2015). Bidirectional citation searching to completion: An exploration of literature searching methods. PharmacoEconomics, 33(1), 5-11. https://doi.org/10.1007/s40273014-0205-3

HM Treasury. (2020). Magenta book. HM Treasury. https://assets.publishing.service.gov.uk/government/uploads/system/uploads/attachment_data/file/87 9438/HMT_Magenta_Book.pdf

Hulland, J., \& Houston, M. B. (2020). Why systematic review papers and meta-analyses matter: An introduction to the special issue on generalizations in marketing. Journal of the Academy of Marketing Science, 48(3), 351-359. https://doi.org/10.1007/s11747-020-00721-7

Hultcrantz, M., Rind, D., Akl, E. A., Treweek, S., Mustafa, R. A., Iorio, A., Alper, B. S., Meerpohl, J. J., Murad, M. H., Ansari, M. T., Katikireddi, S. V., Östlund, P., Tranæus, S., Christensen, R., Gartlehner, G., Brozek, J., Izcovich, A., Schünemann, H., \& Guyatt, G. (2017). The GRADE Working Group clarifies the construct of certainty of evidence. Journal of Clinical Epidemiology, 87, 4-13. https://doi.org/10.1016/j.jclinepi.2017.05.006

Hung, C. (2020). Commercialization and nonprofit donations: A meta-analytic assessment and extension. Nonprofit Management \& Leadership, 31(2), 287-309. https://doi.org/10.1002/nml.21435

Jenni, K., \& Loewenstein, G. (1997). Explaining the Identifiable Victim Effect. Journal of Risk and Uncertainty, 14(3), 235-257. https://doi.org/10.1023/A:1007740225484

Jung, H., Seo, E., Han, E., Henderson, \& Patall, E. A. (2020). Prosocial modeling: A meta-analytic review and synthesis. Psychological Bulletin, 146(8), 635-663. https://doi.org/10.1037/bul0000235 Khangura, S., Konnyu, K., Cushman, R., Grimshaw, J., \& Moher, D. (2012). Evidence summaries: the evolution of a rapid review approach. Systematic Reviews, 1, 10. https://doi.org/10.1186/2046-40531-10 
Kinnunen, S. P., \& Windmann, S. (2013). Dual-processing altruism. Frontiers in Psychology, 4(193), 193. https://doi.org/10.3389/fpsyg.2013.00193

Lasswell, H. D. (1948). The structure and function of communication in society. The Communication of Ideas, 37(1), 136-139. http://www.irfanerdogan.com/dergiweb2008/24/12.pdf

Lee, S., \& Feeley, T. H. (2017). A meta-analysis of the pique technique of compliance. Soc. Influ., 12(1), 15-28. https://doi.org/10.1080/15534510.2017.1305986

Lee, S., Moon, S.-I., \& Feeley, T. H. (2016). A Meta-Analytic Review of the Legitimization of Paltry Favors Compliance Strategy. Psychological Reports, 118(3), 748-771. https://doi.org/10.1177/0033294116647690

Lu, J. (2016). The Philanthropic Consequence of Government Grants to Nonprofit Organizations: A Meta-Analysis. Nonprofit Management \& Leadership, 26(4), 381-400. https://doi.org/10.1002/nml.21203

MacAskill, W. (2015). Doing Good Better: How Effective Altruism Can Help You Make a Difference. Avery. https://www.amazon.com/Doing-Good-Better-Effective-Difference/dp/1592409105

Mazodier, M., Carrillat, F. A., Sherman, C., \& Plewa, C. (2020). Can donations be too little or too much? European Journal of Marketing. https://doi.org/10.1108/EJM-03-2019-0278

Moher, D., Liberati, A., Tetzlaff, J., Altman, D. G., \& PRISMA Group. (2010). Preferred reporting items for systematic reviews and meta-analyses: the PRISMA statement. International Journal of Surgery, 8(5), 336-341. https://doi.org/10.1016/j.ijsu.2010.02.007

Nagel, J., \& Waldmann, M. R. (2016). On having very long arms: how the availability of technological means affects moral cognition. Thinking \& Reasoning, 22(2), 184-208. https://doi.org/10.1080/13546783.2015.1114023

Northover, S. B., Pedersen, W. C., Cohen, A. B., \& Andrews, P. W. (2017). Artificial surveillance cues do not increase generosity: Two meta-analyses. Evolution and Human Behavior: Official Journal of the Human Behavior and Evolution Society, 38(1), 144-153. 
https://doi.org/10.1016/j.evolhumbehav.2016.07.001

Oppenheimer, D. M., \& Olivola, C. Y. (2010). The Science of Giving: Experimental Approaches to the Study of Charity. Taylor \& Francis. https://play.google.com/store/books/details?id=751YfqybBioC

Page, M. J., McKenzie, J. E., Bossuyt, P. M., Boutron, I., Hoffmann, T. C., Mulrow, C. D., Shamseer, L., Tetzlaff, J. M., \& Moher, D. (2021). Updating guidance for reporting systematic reviews: development of the PRISMA 2020 statement. Journal of Clinical Epidemiology, 134, 103-112. https://doi.org/10.1016/j.jclinepi.2021.02.003

Peloza, J., \& Steel, P. (2005). The price elasticities of charitable contributions: A meta-analysis. Journal of Public Policy \& Marketing, 24(2), 260-272. https://doi.org/10.1509/jppm.2005.24.2.260

Pham, C., \& Septianto, F. (2019). A smile - the key to everybody's heart?: The interactive effects of image and message in increasing charitable behavior. European Journal of Marketing, 54(2), 261281. https://doi.org/10.1108/EJM-01-2019-0019

Pollock, A., Campbell, P., Brunton, G., Hunt, H., \& Estcourt, L. (2017). Selecting and implementing overview methods: implications from five exemplar overviews. Systematic Reviews, 6(1), 145. https://doi.org/10.1186/s13643-017-0534-3

R Core Team. (2020). R: A language and environment for statistical computing (Version 3.6.3) [Computer software]. R Foundation for Statistical Computing. https://www.R-project.org/ Richard, F. D., Bond, C. F., \& Stokes-Zoota, J. J. (2003). One Hundred Years of Social Psychology Quantitatively Described. Review of General Psychology: Journal of Division 1, of the American Psychological Association, 7(4), 331-363. https://doi.org/10.1037/1089-2680.7.4.331

Rothschild, M. L. (1979). Marketing communications in nonbusiness situations or why it's so hard to sell brotherhood like soap. Journal of Marketing, 43, 11-20. https://www.ncbi.nlm.nih.gov/pubmed/12267408

Saeri, A. K., Slattery, P., Tear, M. J., Varazzani, C., Epstein, D., Knott, C., Kusmanoff, A., Bagshaw, H., Phillips, K., Liao, J., Orjuela, S., \& Smith, A. L. (2021). Scale up of behaviour change interventions: 
A rapid review of evidence and practice. https://doi.org/10.31219/osf.io/scd3k

Schmidt, F. L., \& Oh, I.-S. (2013). Methods for second order meta-analysis and illustrative applications. Organizational Behavior and Human Decision Processes, 121(2), 204-218. https://doi.org/10.1016/j.obhdp.2013.03.002

Septianto, F., Tjiptono, F., Paramita, W., \& Chiew, T. M. (2020). The interactive effects of religiosity and recognition in increasing donation. European Journal of Marketing. https://doi.org/10.1108/EJM-042019-0326

Shea, B. J., Reeves, B. C., Wells, G., Thuku, M., Hamel, C., Moran, J., Moher, D., Tugwell, P., Welch, V., Kristjansson, E., \& Henry, D. A. (2017). AMSTAR 2: a critical appraisal tool for systematic reviews that include randomised or non-randomised studies of healthcare interventions, or both. $B M J$ , 358, j4008. https://doi.org/10.1136/bmj.j4008

Singer, P. (2019). The Life You Can Save, 10th Anniversary Edition. www.thelifeyoucansave.org. https://www.booktopia.com.au/10th-anniversary-edition-the-life-you-can-save-petersinger/book/9781733672702.html

Slattery, P., Vidgen, R., \& Finnegan, P. (2020). Persuasion: An analysis and common frame of reference for IS research. Communications of the Association for Information Systems, 46(1), 3. https://doi.org/10.17705/1CAIS.04603

Sparks, A., \& Barclay, P. (2013). Eye images increase generosity, but not for long: the limited effect of a false cue. Evolution and Human Behavior: Official Journal of the Human Behavior and Evolution Society, 34(5), 317-322. https://doi.org/10.1016/j.evolhumbehav.2013.05.001

Stanley, T. D., Carter, E. C., \& Doucouliagos, H. (2018). What meta-analyses reveal about the replicability of psychological research. Psychological Bulletin, 144(12), 1325-1346. https://doi.org/10.1037/bul0000169

Stannard-Stockton, S. (2009, December 10). Appealing to Donors' Hearts and Heads. The Chronicle of Philanthropy. https://www.philanthropy.com/article/Appealing-to-Donors-Hearts/173425 
Sterne, J. A. C., Savović, J., Page, M. J., Elbers, R. G., Blencowe, N. S., Boutron, I., Cates, C. J., Cheng, H.-Y., Corbett, M. S., Eldridge, S. M., Emberson, J. R., Hernán, M. A., Hopewell, S., Hróbjartsson, A., Junqueira, D. R., Jüni, P., Kirkham, J. J., Lasserson, T., Li, T., ... Higgins, J. P. T. (2019). RoB 2: a revised tool for assessing risk of bias in randomised trials [Review of RoB 2: a revised tool for assessing risk of bias in randomised trials]. BMJ , 366, 14898. https://doi.org/10.1136/bmj.14898

Wallace, E., Buil, I., \& de Chernatony, L. (2017). When does "liking" a charity lead to donation behaviour?: Exploring conspicuous donation behaviour on social media platforms. European Journal of Marketing, 51(11-12), 2002-2029. https://doi.org/10.1108/EJM-03-2017-0210

Weyant, J. M. (1996). Application of compliance techniques to direct-mail requests for charitable donations. Psychology and Marketing, 13(2), 157-170. https://doi.org/10.1002/(SICI)15206793(199602)13:2<157::AID-MAR3>3.0.CO;2-E

Wiepking, P., \& Bekkers, R. (2012). Who gives? A literature review of predictors of charitable giving. Part Two: Gender, family composition and income. Voluntary Sector Review. https://www.ingentaconnect.com/content/tpp/vsr/2012/00000003/00000002/art00005

World Health Organisation. (2017). Rapid reviews to strengthen health policy and systems: a practical guide. World Health Organization. https://www.who.int/alliance-hpsr/resources/publications/rapidreview-guide/en/ 


\section{Additional references}

Xu, J., \& Huang, G. (2020). The relative effectiveness of gain-framed and loss-framed messages in charity advertising: Meta-analytic evidence and implications. International Journal of Nonprofit and Voluntary Sector Marketing, 25(4), e1675. https://doi.org/10.1002/nvsm.1675

Larney, A., Rotella, A., \& Barclay, P. (2019). Stake size effects in ultimatum game and dictator game offers: A meta-analysis. Organizational Behavior and Human Decision Processes, 151, 61-72. https://doi.org/10.1016/j.obhdp.2019.01.002

Nettle, D., Harper, Z., Kidson, A., Stone, R., Penton-Voak, I. S., \& Bateson, M. (2013). The watching eyes effect in the Dictator Game: it's not how much you give, it's being seen to give something. Evolution and Human Behavior, 34(1), 35-40.

Eisend, M. (2015). Have we progressed marketing knowledge? A meta-meta-analysis of effect sizes in marketing research. Journal of Marketing, 79(3), 23-40. https://doi.org/10.1509/jm.14.0288

Eisend, M., \& Tarrahi, F. (2016). The effectiveness of advertising: A meta-meta-analysis of advertising inputs and outcomes. Journal of Advertising, 45(4), 519-531. https://doi.org/10.1080/00913367.2016.1185981

Bennett, R. (2016). Preventing charity website browsers from quitting the "donate now" page: A case study with recommendations. Social Business, 6(3), 291-306.

https://doi.org/10.1362/204440816x14811339560974

Salido-Andres, N., Rey-Garcia, M., Alvarez-Gonzalez, L. I., \& Vazquez-Casielles, R. (2021). Mapping the field of donation-based crowdfunding for charitable causes: systematic review and conceptual framework. VOLUNTAS: International Journal of Voluntary and Nonprofit Organizations, 32(2), 288-302. https://doi.org/10.1007/s11266-020-00213-w

Rand, D. G., Brescoll, V. L., Everett, J. A., Capraro, V., \& Barcelo, H. (2016). Social heuristics and social roles: Intuition favors altruism for women but not for men. Journal of Experimental Psychology: General, 145(4), 389. https://doi.org/10.1037/xge0000154 
Open Science Collaboration. (2015). Estimating the reproducibility of psychological science. Science, 349(6251), aac4716. https://doi.org/10.1126/science.aac4716 


\section{Supplementary File 1. Internal and external validity assessment for included reviews}

\section{Quality Appraisal of the Included Reviews}

We assessed the quality of the included reviews using an abbreviated list of quality criteria drawn from AMSTAR 2 (Shea et al., 2017). The full AMSTAR2 tool was developed on the basis of a scoping review of tools for assessing the quality of systematic reviews, followed by iterative workshops with content experts (Shea et al., 2017). This abbreviated list has been used to assess core quality requirements for marketing systematic reviews, such as those discussed by Palmatier and colleagues (2018): focused question, comprehensive search, clear inclusion/exclusion, duplicate screening, duplicate quality assessment, presentation of each included study, assessment of heterogeneity, and assessment of publication bias. These quality assessment items are judged to be the most important in assessing the reliability and validity of systematic reviews (National Heart, Lung, and Blood Institute [NHLBI], n.d.) and deliberately omit AMSTAR 2 criteria that are unlikely to be relevant in marketing (e.g., searching trial registries). The 'comprehensive search' criteria assessed whether the search strategy was likely to find the majority of studies meeting inclusion criteria. The 'clear inclusion/exclusion' criteria assessed the reproducibility of the systematic review's eligibility criteria. The 'duplicate screening' and 'duplicate quality assessment' criteria assess whether tasks prone to consequential errors or judgement are done in duplicate. The 'presentation of each included study' criteria assessed the transparency of the results from the systematic review, used to inform conclusions. Finally, the 'assessment of heterogeneity' and 'assessment of publication bias' criteria assessed how well the reviews accounted for these two sources of uncertainty in conclusions. Low quality reviews were kept in this meta-review but used to qualify the certainty of the findings. 
Results from our quality appraisal are available in Supplementary Table S1. All reviews except two asked a focused question and presented each study included in the review (usually through a Characteristics of Included Studies table). Most (16/21) clearly specified their inclusion criteria and over half conducted a comprehensive search (14/21). Only two clearly described duplicate screening, and only one review clearly described duplicate quality assessment (Jung et al., 2020). This quality assessment critiqued an important area (blinding) but omitted all other key threats to internal validity (e.g., selective reporting; Higgins et al., 2011). Half of the reviews tested for publication bias (10/21) and fifteen explicitly assessed heterogeneity. 


\section{Supplementary Table S1}

Results From Quality Appraisal of the Included Reviews

\begin{tabular}{|c|c|c|c|c|c|c|c|c|}
\hline Review & $\begin{array}{l}\text { Focused } \\
\text { question }\end{array}$ & $\begin{array}{l}\text { Inclusion } \\
\text { prespecified }\end{array}$ & $\begin{array}{l}\text { Comprehensive } \\
\text { search }\end{array}$ & $\begin{array}{l}\text { Duplicate } \\
\text { screening }\end{array}$ & $\begin{array}{l}\text { Duplicate } \\
\text { quality } \\
\text { assessment }\end{array}$ & $\begin{array}{l}\text { All studies } \\
\text { described }\end{array}$ & $\begin{array}{l}\text { Publication } \\
\text { bias assessed }\end{array}$ & $\begin{array}{l}\text { Heterogeneity } \\
\text { assessed }\end{array}$ \\
\hline Andrews et al., 2008 & Yes & Yes & Yes & NR & NA & Yes & Yes & Yes \\
\hline Bolkan \& Rains, 2017 & Yes & Yes & No & NR & NA & Yes & No & No \\
\hline Bradley et al., 2018 & Yes & Yes & Yes & NR & NA & Yes & Yes & Yes \\
\hline Butts et al., 2019 & Yes & Yes & Yes & Yes & NA & Yes & No & No \\
\hline Coyne et al., 2018 & Yes & Yes & Yes & Yes & NA & Yes & Yes & Yes \\
\hline de Wit \& Bekkers, 2017 & Yes & Yes & No & NR & NA & Yes & No & Yes \\
\hline Engel, 2011 & No & No & No & No & NA & No & No & Yes \\
\hline Feeley et al., 2012 & Yes & Yes & Yes & No & NA & Yes & Yes & Yes \\
\hline Fromell et al., 2020 & Yes & Yes & No & NR & NA & Yes & No & Yes \\
\hline Jung et al., 2020 & Yes & Yes & Yes & NR & Yes & Yes & Yes & Yes \\
\hline Larney et al., 2019 & Yes & Yes & Yes & NR & NA & Yes & Yes & Yes \\
\hline Lee et al., 2016 & Yes & Yes & Yes & NR & NA & Yes & No & Yes \\
\hline Lee \& Feeley, 2017 & Yes & Yes & Yes & NR & NA & Yes & Yes & Yes \\
\hline Lu, 2016 & Yes & Yes & Yes & NR & NA & Yes & Yes & Yes \\
\hline Nettle et al., 2013 & Yes & No & No & NR & NA & Yes & No & No \\
\hline Northover et al., 2017 & Yes & Yes & Yes & NR & NA & Yes & No & Yes \\
\hline Peloza \& Steel, 2005 & Yes & Yes & Yes & NR & NA & Yes & Yes & No \\
\hline Rand et al., 2016 & Yes & No & $\mathrm{CD}$ & NR & NA & Yes & Yes & Yes \\
\hline Salido-Andres et al., 2020 & No & No & Yes & NR & NA & No & No & No \\
\hline Sparks \& Barclay, 2013 & Yes & No & $\mathrm{CD}$ & NR & NA & Yes & No & No \\
\hline Xu \& Huang, 2020 & Yes & Yes & Yes & NR & NA & Yes & No & Yes \\
\hline
\end{tabular}

Note $. \mathrm{NR}=$ not reported, $\mathrm{CD}=$ Cannot determine, $\mathrm{NA}=$ Not applicable 


\section{Certainty Assessment}

Where quality assessment considers each review separately, certainty assessment considers the quality of the evidence across all evidence for each combination of intervention and outcome (Guyatt et al., 2011; Higgins et al., 2019; Hultcrantz et al., 2017). The best-practice method of certainty assessment is the GRADE approach (Guyatt et al., 2011; Higgins et al., 2019; Hultcrantz et al., 2017). GRADE does not assess the size of an effect, per-se, but the confidence readers should have in the findings. The method considers both internal and external validity of the evidence for the intervention. A series of randomised experiments is given a rating of 'high certainty', but confidence is downgraded for one of five reasons (Guyatt et al., 2011; Hultcrantz et al., 2017): high risk of bias among the randomised experiments, high risk of publication bias, imprecise findings (usually indicated by wide confidence intervals), inconsistency (usually indicated by high unexplained heterogeneity), and indirectness (i.e., low external validity). Studies can also be upgraded for having large effect sizes (so biases would seldom negate the benefit), a dose-response gradient where more of the intervention leads to better results, and where any residual confounding would lead to increased rather than decreased effects (Guyatt et al., 2011; Hultcrantz et al., 2017). While this method is seldom used in marketing, it answers a key question practitioners and researchers want to know: how confident should I be in this effect? The criteria are drawn from meta-reviews of experimental biases that have been shown to add uncertainty to effect sizes, usually in the direction of inflating reported effects (Guyatt et al., 2011; Hultcrantz et al., 2017).

\section{Certainty Assessments}

Our certainty assessment (GRADE, Hultcrantz et al., 2017) found key threats to internal and external validity of the interventions reported in the included reviews, which reduce our 
certainty in all reported effects (see Supplementary Table S2). One intervention received a GRADE of 'low' ("The true effect might be markedly different from the estimated effect") because the effect sizes were large enough that the threats to internal and external validity would seldom eliminate effects entirely (pique technique; Lee \& Feeley, 2017). All other interventions received a GRADE of 'very low' ("The true effect is probably markedly different from the estimated effect"). 


\section{Supplementary Table S2}

GRADE Table with Pooled Effect for Each Intervention and Confidence in that Effect Size Estimate (GRADE) from High to Very Low

\begin{tabular}{|c|c|c|c|c|c|c|c|c|c|c|}
\hline Intervention & Outcome & $\begin{array}{l}r \text { with } \\
95 \% \mathrm{CI}\end{array}$ & GRADE & Design & $\begin{array}{l}\text { Risk } \\
\text { of Bias }\end{array}$ & Imprecision & Inconsistency & Indirectness & $\begin{array}{l}\text { Publication } \\
\text { Bias }\end{array}$ & $\begin{array}{l}\text { Large } \\
\text { Effect }\end{array}$ \\
\hline $\begin{array}{l}\text { Crowding } \\
\text { out }\end{array}$ & $\begin{array}{l}\text { Donation } \\
\text { revenue }\end{array}$ & Uncertain & Very low & $\begin{array}{l}\text { Both } \\
\text { experimental } \\
\text { and non- } \\
\text { experimental } \\
\text { studies }\end{array}$ & NA & $\begin{array}{l}\text { Wide CIs and } \\
\text { divergent } \\
\text { results for } \\
\text { experimental } \\
\text { and non- } \\
\text { experimental } \\
\text { studies }\end{array}$ & $\begin{array}{l}\text { Large } \\
\text { between-study } \\
\text { standard } \\
\text { deviation } \\
\text { (often }>= \\
\text { effect size) }\end{array}$ & $\begin{array}{l}\text { Mostly field } \\
\text { experiments }\end{array}$ & $\begin{array}{l}\text { Not } \\
\text { assessed }\end{array}$ & $\begin{array}{l}\text { No } \\
|\mathrm{r}|<0.3\end{array}$ \\
\hline $\begin{array}{l}\text { Door in the } \\
\text { face }\end{array}$ & Compliance & $\begin{array}{l}0.06 \\
{[-0.01,0.12]}\end{array}$ & Very low & $\begin{array}{l}\text { Apparently } \\
\text { experimental } \\
\text { studies }\end{array}$ & $\mathrm{NA}$ & $\begin{array}{l}\text { Wide } \\
\text { confidence } \\
\text { intervals for } \\
\text { monetary } \\
\text { donations }\end{array}$ & $\begin{array}{l}\text { Significant } \\
\text { unexplained } \\
\text { heterogeneity }\end{array}$ & $\begin{array}{l}\text { About half of the } \\
\text { studies involved } \\
\text { students with } \\
\text { smaller effects in } \\
\text { non-student } \\
\text { populations }\end{array}$ & $\begin{array}{l}\text { Assessed } \\
\text { and low risk }\end{array}$ & $\begin{array}{l}\text { No } \\
|\mathrm{r}|<0.3\end{array}$ \\
\hline $\begin{array}{l}\text { Gain-framed } \\
\text { messages }\end{array}$ & $\begin{array}{l}\text { Donation } \\
\text { size }\end{array}$ & $\begin{array}{l}-0.01 \\
{[-0.09,0.07]}\end{array}$ & Very low & $\begin{array}{l}\text { Randomised } \\
\text { experiments }\end{array}$ & $\mathrm{NA}$ & Narrow CI & $\begin{array}{l}\text { Large } \\
\text { between study } \\
\text { heterogeneity } \\
(88.47 \%)\end{array}$ & $\begin{array}{l}\text { Mostly field } \\
\text { experiments } \\
\text { (26/40) with no } \\
\text { significant } \\
\text { difference in } \\
\text { pattern. }\end{array}$ & $\begin{array}{l}\text { Not } \\
\text { assessed by } \\
\text { established } \\
\text { methods; } \\
\text { methods } \\
\text { used } \\
\text { indicated } \\
\text { presence of } \\
\text { bias }\end{array}$ & $\begin{array}{l}\text { No } \\
|\mathrm{r}|<0.3\end{array}$ \\
\hline $\begin{array}{l}\text { Identifiable } \\
\text { victim }\end{array}$ & $\begin{array}{l}\text { Donation } \\
\text { size }\end{array}$ & $\begin{array}{l}0.13 \\
{[0.08,0.17]}\end{array}$ & Very low & $\begin{array}{l}\text { Could be } \\
\text { either } \\
\text { randomised } \\
\text { or quasi- } \\
\text { experimental; } \\
\text { proportion } \\
\text { not reported }\end{array}$ & NA & Narrow CI & $\begin{array}{l}\text { Moderate } \\
\text { unexplained } \\
\text { heterogeneity } \\
(53 \%)\end{array}$ & $\begin{array}{l}\text { Approximately } 3 \\
\text { of } 40+\text { studies } \\
\text { were field } \\
\text { experiments, the } \\
\text { rest conducted in } \\
\text { laboratories }\end{array}$ & $\begin{array}{l}\text { Not } \\
\text { assessed }\end{array}$ & $\begin{array}{l}\text { No } \\
|\mathrm{r}|<0.3\end{array}$ \\
\hline $\begin{array}{l}\text { Legitimizing } \\
\text { paltry } \\
\text { contributions }\end{array}$ & Compliance & $\begin{array}{l}0.22 \\
{[0.17,0.26]}\end{array}$ & Very low & $\begin{array}{l}\text { Randomised } \\
\text { experiments }\end{array}$ & NA & $\begin{array}{l}\text { Wide CI } \\
\text { ranging from } \\
\text { no effect to }\end{array}$ & $\begin{array}{l}\text { Significant } \\
\text { heterogeneity } \\
\text { for } \\
\text { compliance }\end{array}$ & $\begin{array}{l}\text { Only } 2 / 17 \text { studies } \\
\text { conducted in lab }\end{array}$ & $\begin{array}{l}\text { Not } \\
\text { assessed }\end{array}$ & $\begin{array}{l}\text { No } \\
|\mathrm{r}|<0.3\end{array}$ \\
\hline
\end{tabular}




\begin{tabular}{|c|c|c|c|c|c|c|c|c|c|c|}
\hline Intervention & Outcome & $\begin{array}{l}r \text { with } \\
95 \% \mathrm{CI}\end{array}$ & GRADE & Design & $\begin{array}{l}\text { Risk } \\
\text { of Bias }\end{array}$ & Imprecision & Inconsistency & Indirectness & $\begin{array}{l}\text { Publication } \\
\text { Bias }\end{array}$ & $\begin{array}{l}\text { Large } \\
\text { Effect }\end{array}$ \\
\hline & & & & & & $\begin{array}{l}\text { possibly very } \\
\text { harmful }\end{array}$ & & & & \\
\hline & $\begin{array}{l}\text { Donation } \\
\text { size }\end{array}$ & $\begin{array}{l}-0.14 \\
{[-0.22,-} \\
0.06]\end{array}$ & Very low & $\begin{array}{l}\text { Randomised } \\
\text { experiments }\end{array}$ & NA & $\begin{array}{l}\text { Wide CI } \\
\text { ranging from } \\
\text { no effect to } \\
\text { possibly very } \\
\text { harmful }\end{array}$ & $\begin{array}{l}\text { No significant } \\
\text { heterogeneity } \\
\text { for donation } \\
\text { size }\end{array}$ & $\begin{array}{l}\text { Only } 2 / 30 \text { studies } \\
\text { conducted in lab }\end{array}$ & NA & $\begin{array}{l}\text { No } \\
|r|<0.3\end{array}$ \\
\hline \multirow[t]{2}{*}{$\begin{array}{l}\text { Observability } \\
\text { (artificial) }\end{array}$} & Compliance & $\begin{array}{l}0.04 \\
{[0.03,0.06]}\end{array}$ & Very low & $\begin{array}{l}\text { Randomised } \\
\text { experiments }\end{array}$ & $\mathrm{NA}$ & Narrow CI & $\begin{array}{l}\text { No significant } \\
\text { heterogeneity } \\
\text { for } \\
\text { compliance }\end{array}$ & $\begin{array}{l}\text { Some field } \\
\text { experiments but } \\
\text { most in lab and no } \\
\text { moderation } \\
\text { conducted }\end{array}$ & $\mathrm{NA}$ & $\begin{array}{l}\text { No } \\
|r|<0.3\end{array}$ \\
\hline & $\begin{array}{l}\text { Donation } \\
\text { size }\end{array}$ & $\begin{array}{l}0.01 \\
{[-0.02,0.05]}\end{array}$ & Very low & $\begin{array}{l}\text { Randomised } \\
\text { experiments }\end{array}$ & NA & Narrow CI & $\begin{array}{l}\text { Significant } \\
\text { heterogeneity } \\
\text { for donation } \\
\text { size }\end{array}$ & $\begin{array}{l}\text { Some field } \\
\text { experiments but } \\
\text { most in lab and no } \\
\text { moderation } \\
\text { conducted }\end{array}$ & NA & $\begin{array}{l}\text { No } \\
|r|<0.3\end{array}$ \\
\hline $\begin{array}{l}\text { Observability } \\
\text { (real) }\end{array}$ & $\begin{array}{l}\text { Donation } \\
\text { size }\end{array}$ & $\begin{array}{l}0.15 \\
{[0.11,0.20]}\end{array}$ & Very low & $\begin{array}{l}73 \% \\
\text { experimental } \\
\text { studies }\end{array}$ & NA & Narrow CI & $\begin{array}{l}\text { Large } \\
\text { heterogeneity } \\
(99.24 \%) \text { that } \\
\text { appears } \\
\text { unexplained }\end{array}$ & $\begin{array}{l}\text { Most studies } \\
\text { conducted in } \\
\text { laboratories } \\
(\sim 99 / 134) \text { with } \\
\text { much lower effects } \\
\text { from field } \\
\text { experiments }\end{array}$ & $\begin{array}{l}\text { Assessed } \\
\text { and low risk }\end{array}$ & $\begin{array}{l}\text { No } \\
|r|<0.3\end{array}$ \\
\hline \multirow[t]{2}{*}{ Pique } & Compliance & $\begin{array}{l}0.27 \\
{[0.19,0.35]}\end{array}$ & Low & $\begin{array}{l}\text { Randomised } \\
\text { experiments }\end{array}$ & NA & Narrow CI & $\begin{array}{l}\text { Significant } \\
\text { unexplained } \\
\text { heterogeneity }\end{array}$ & $\begin{array}{l}\text { Only } 15 / 17 \text { were } \\
\text { field experiments } \\
\text { but all were trivial } \\
\text { amounts of money } \\
(<\$ 3)\end{array}$ & $\begin{array}{l}\text { Assessed } \\
\text { and low risk }\end{array}$ & $\begin{array}{l}\text { Yes } \\
|\mathrm{r}| \sim= \\
0.3\end{array}$ \\
\hline & $\begin{array}{l}\text { Donation } \\
\text { size }\end{array}$ & $\begin{array}{l}0.29 \\
{[0.25,0.33]}\end{array}$ & Low & $\begin{array}{l}\text { Randomised } \\
\text { experiments }\end{array}$ & NA & Narrow CI & NA & $\begin{array}{l}\text { Only } 15 / 17 \text { were } \\
\text { field experiments } \\
\text { but all were trivial } \\
\text { amounts of money } \\
(<\$ 3)\end{array}$ & $\begin{array}{l}\text { Assessed } \\
\text { and low risk }\end{array}$ & $\begin{array}{l}\text { Yes } \\
|\mathrm{r}| \sim= \\
0.3\end{array}$ \\
\hline
\end{tabular}




\begin{tabular}{|c|c|c|c|c|c|c|c|c|c|c|}
\hline Intervention & Outcome & $\begin{array}{l}r \text { with } \\
95 \% \mathrm{CI}\end{array}$ & GRADE & Design & $\begin{array}{l}\text { Risk } \\
\text { of Bias }\end{array}$ & Imprecision & Inconsistency & Indirectness & $\begin{array}{l}\text { Publication } \\
\text { Bias }\end{array}$ & $\begin{array}{l}\text { Large } \\
\text { Effect }\end{array}$ \\
\hline $\begin{array}{l}\text { Promoting } \\
\text { intuition } \\
\text { instead of } \\
\text { deliberation }\end{array}$ & $\begin{array}{l}\text { Donation } \\
\text { size }\end{array}$ & $\begin{array}{l}-0.01 \\
{[-0.02,0.01]}\end{array}$ & Very low & $\begin{array}{l}\text { Randomised } \\
\text { experiments }\end{array}$ & NA & Narrow CI & $\begin{array}{l}\text { Difficult to } \\
\text { assess as } \\
\text { described }\end{array}$ & $\begin{array}{l}\text { Unclear, presumed } \\
\text { to be mostly } \\
\text { laboratory } \\
\text { experiments }\end{array}$ & NA & $\begin{array}{l}\text { No } \\
|\mathrm{r}|<0.3\end{array}$ \\
\hline $\begin{array}{l}\text { Prosocial } \\
\text { media }\end{array}$ & $\begin{array}{l}\text { Donation } \\
\text { size }\end{array}$ & $\begin{array}{l}0.09 \\
{[-0.04,0.21]}\end{array}$ & Very low & $\begin{array}{l}\text { Mostly } \\
\text { experimental } \\
\text { studies } \\
(57 / 77)\end{array}$ & NA & $\begin{array}{l}\text { Wide CI } \\
\text { ranging from } \\
\text { no effect to } \\
\text { possibly very } \\
\text { helpful }\end{array}$ & $\begin{array}{l}\text { Large } \\
\text { unexplained } \\
\text { heterogeneity } \\
(77.90 \%)\end{array}$ & $\begin{array}{l}\text { Most appear to be } \\
\text { in laboratory } \\
\text { settings }\end{array}$ & $\begin{array}{l}\text { Assessed } \\
\text { and present, } \\
\text { not } \\
\text { corrected } \\
\text { for in } \\
\text { analyses }\end{array}$ & $\begin{array}{l}\text { No } \\
|r|<0.3\end{array}$ \\
\hline $\begin{array}{l}\text { Prosocial } \\
\text { modelling }\end{array}$ & $\begin{array}{l}\text { Donation } \\
\text { size }\end{array}$ & $\begin{array}{l}0.22 \\
{[0.21,0.24]}\end{array}$ & Very low & $\begin{array}{l}\text { Randomised } \\
\text { experiments }\end{array}$ & $\begin{array}{l}21 / 88 \\
\text { studies } \\
\text { were } \\
\text { blinde } \\
\text { d with } \\
\text { similar } \\
\text { effect } \\
\text { sizes }\end{array}$ & $\begin{array}{l}\text { Narrow } \\
\text { confidence } \\
\text { interval }\end{array}$ & $\begin{array}{l}\text { Large } \\
\text { between study } \\
\text { heterogeneity } \\
(73.2 \%)\end{array}$ & $\begin{array}{l}\text { Mostly lab } \\
\text { experiments } \\
(65 / 88) \text { with some } \\
\text { field and online } \\
\text { studies, with larger } \\
\text { effects in the lab }\end{array}$ & $\begin{array}{l}\text { Assessed } \\
\text { and present } \\
\text { but } \\
\text { corrected } \\
\text { for in } \\
\text { analyses }\end{array}$ & $\begin{array}{l}\text { No } \\
|r|<0.3\end{array}$ \\
\hline $\begin{array}{l}\text { Tax } \\
\text { deductibility }\end{array}$ & $\begin{array}{l}\text { Price } \\
\text { elasticity }\end{array}$ & $\begin{array}{l}-1.44 \\
{[\mathrm{NR}, \mathrm{NR}]}\end{array}$ & Very low & $\begin{array}{l}\text { Observational } \\
\text { data }\end{array}$ & NA & $\begin{array}{l}\text { Very wide } \\
\text { standard } \\
\text { deviation, CI } \\
\text { not reported }\end{array}$ & NA & Largely field data & $\begin{array}{l}\text { Assessed } \\
\text { and low risk }\end{array}$ & $\begin{array}{l}\text { No } \\
|\mathrm{r}|<0.3\end{array}$ \\
\hline
\end{tabular}

Note: No effects had robust dose-response gradients (upgrade criteria \#2) or appeared to be in a context where residual confounding would have increased effects (upgrade criteria \#3), so we omitted those columns. NA = Not assessed. 


\section{Supplementary File 2. Contexts Mapped by the Included Reviews}

The included reviews synthesised research addressing charitable donations in diverse ways (see Supplementary Table S3). Many explored how variations in economic games influenced donation. Many also found a number of studies conducted in the field, but usually only included small donations. We mapped the contexts examined by the various reviews by context, channel, and persuasion methods (Lasswell, 1948; Slattery et al., 2020). 


\section{Supplementary Table S3}

Review Context Categorization: Who used What Method and Channel, Who Received It, How Was the Outcome Assessed, and How Was the Data collected?

\begin{tabular}{|c|c|c|c|c|c|c|}
\hline Who & Method of persuasion & $\begin{array}{l}\text { Bekkers \& } \\
\text { Wiepking } \\
\text { (2011b) } \\
\text { Mechanism } \\
\end{array}$ & $\begin{array}{l}\text { Channel of } \\
\text { communication }\end{array}$ & Receiver & Outcome measured & $\begin{array}{l}\text { Data collection } \\
\operatorname{context}(s)\end{array}$ \\
\hline $\begin{array}{l}\text { Andrews et } \\
\text { al., } 2008\end{array}$ & $\begin{array}{l}\text { Encouraging even small } \\
\text { requests for donations } \\
\text { ('legitimizing paltry } \\
\text { contributions') }\end{array}$ & Costs and benefits & $\begin{array}{l}\text { Almost } \\
\text { exclusively } \\
\text { spoken/face-to- } \\
\text { face (one study } \\
\text { via mail) }\end{array}$ & Individuals, presumably adults & One off donation & $\begin{array}{l}\text { Usually in public or } \\
\text { participant's home }\end{array}$ \\
\hline $\begin{array}{l}\text { Bolkan \& } \\
\text { Rains, } 2017\end{array}$ & $\begin{array}{l}\text { Small requests for } \\
\text { donation/Paltry } \\
\text { contributions }\end{array}$ & Costs and benefits & $\begin{array}{l}\text { Spoken/Face-to- } \\
\text { face }\end{array}$ & $\begin{array}{l}\text { Individuals, presumably adults } \\
\text { and students predominantly }\end{array}$ & One off donation & $\begin{array}{l}\text { Experimental; otherwise } \\
\text { not specified or implied. }\end{array}$ \\
\hline $\begin{array}{l}\text { Bradley et } \\
\text { al., } 2018\end{array}$ & $\begin{array}{l}\text { Any form of } \\
\text { observation by others }\end{array}$ & Reputation & $\begin{array}{l}\text { Various, } \\
\text { including overt } \\
\text { observation (e.g., } \\
\text { bystander), } \\
\text { pseudo- } \\
\text { observation (e.g., } \\
\text { post-hoc audit) or } \\
\text { perceived } \\
\text { observation (e.g., } \\
\text { watching eyes) }\end{array}$ & $\begin{array}{l}\text { Both individuals and groups, } \\
\text { across a range of ages }\end{array}$ & $\begin{array}{l}\text { Either one-off or } \\
\text { repeated monetary } \\
\text { donation }\end{array}$ & $\begin{array}{l}\text { Both lab based }(75 \%) \\
\text { and field }(25 \%)\end{array}$ \\
\hline $\begin{array}{l}\text { Butts et al., } \\
2019\end{array}$ & $\begin{array}{l}\text { Showing one victim } \\
\text { versus showing many } \\
\text { victims }\end{array}$ & Awareness & $\begin{array}{l}\text { Not specified or } \\
\text { implied }\end{array}$ & $\begin{array}{l}\text { Individuals, presumably adults } \\
\text { and students }\end{array}$ & $\begin{array}{l}\text { Monetary donations } \\
\text { and donations of } \\
\text { goods }\end{array}$ & $\begin{array}{l}\text { Experimental; usually } \\
\text { lab studies }\end{array}$ \\
\hline $\begin{array}{l}\text { Coyne et al., } \\
2018\end{array}$ & $\begin{array}{l}\text { Exposure to prosocial } \\
\text { media: media showing } \\
\text { voluntary behaviour } \\
\text { intended to benefit } \\
\text { another, excluding } \\
\text { where violence was } \\
\text { involved }\end{array}$ & Efficacy & $\begin{array}{l}\mathrm{TV}, \text { movies, } \\
\text { video games, } \\
\text { music, or music } \\
\text { videos }\end{array}$ & $\begin{array}{l}\text { Individuals, differentiated by } \\
\text { sex and age }\end{array}$ & $\begin{array}{l}\text { Donating to an } \\
\text { unspecified target }\end{array}$ & $\begin{array}{l}\text { Experimental, cross } \\
\text { sectional, longitudinal }\end{array}$ \\
\hline
\end{tabular}




\begin{tabular}{|c|c|c|c|c|c|c|}
\hline Who & Method of persuasion & $\begin{array}{l}\text { Bekkers \& } \\
\text { Wiepking } \\
\text { (2011b) } \\
\text { Mechanism }\end{array}$ & $\begin{array}{l}\text { Channel of } \\
\text { communication }\end{array}$ & Receiver & Outcome measured & $\begin{array}{l}\text { Data collection } \\
\text { context(s) }\end{array}$ \\
\hline $\begin{array}{l}\text { de Wit \& } \\
\text { Bekkers, } \\
2017\end{array}$ & $\begin{array}{l}\text { Providing government } \\
\text { support for non-profits }\end{array}$ & Altruism & $\begin{array}{l}\text { Not specified or } \\
\text { implied }\end{array}$ & $\begin{array}{l}\text { Presumably tax paying } \\
\text { American adults }\end{array}$ & $\begin{array}{l}\text { Donation from } \\
\text { individuals to non- } \\
\text { profits }\end{array}$ & $\begin{array}{l}\text { Four types: laboratory } \\
\text { experiments, survey } \\
\text { experiments, archival } \\
\text { (financial information) } \\
\text { data, and micro-level } \\
\text { survey data. }\end{array}$ \\
\hline Engel, 2011 & $\begin{array}{l}\text { Compared variations of } \\
\text { dictator game; } \\
\text { differentiated by donor } \\
\text { characteristics (e.g., } \\
\text { age, ethnicity), recipient } \\
\text { characteristics (e.g., } \\
\text { 'deserving', social } \\
\text { distance) and contextual } \\
\text { manipulations (e.g., } \\
\text { action space, real } \\
\text { money used or not, } \\
\text { certainty of benefit). }\end{array}$ & $\begin{array}{l}\text { Efficacy, } \\
\text { Reputation, } \\
\text { Awareness, Costs } \\
\text { and Benefits, } \\
\text { Other }\end{array}$ & $\begin{array}{l}\text { Not specified, } \\
\text { method implies } \\
\text { that online and } \\
\text { face-to-face were } \\
\text { used }\end{array}$ & $\begin{array}{l}\text { Individuals differentiated by } \\
\text { number (one or more), race, age } \\
\text { (old, middle, student, old), } \\
\text { student status (student or not), } \\
\text { deservingness of reward (earned } \\
\text { or not earned). }\end{array}$ & $\begin{array}{l}\text { Money offered to } \\
\text { other player(s) }\end{array}$ & $\begin{array}{l}\text { Not specified, but } \\
\text { methods and references } \\
\text { imply lab and online } \\
\text { experiments. }\end{array}$ \\
\hline $\begin{array}{l}\text { Feeley et al., } \\
2012\end{array}$ & $\begin{array}{l}\text { Sequential request (e.g., } \\
\text { door in the face, big } \\
\text { followed by small ask, } \\
\text { or repeated ask for same } \\
\text { outcome); } \\
\text { Differentiated by } \\
\text { whether there was a } \\
\text { reduction in original } \\
\text { request or not, and } \\
\text { whether there was a } \\
\text { delay in the follow up } \\
\text { or not }\end{array}$ & $\begin{array}{l}\text { Costs and } \\
\text { Benefits }\end{array}$ & $\begin{array}{l}\text { Differentiated: } \\
\text { Telephone/Online } \\
\text { /Written or Face- } \\
\text { to-Face }\end{array}$ & $\begin{array}{l}\text { Adults, differentiated into } \\
\text { students, non-students, and } \\
\text { mixed sample }\end{array}$ & 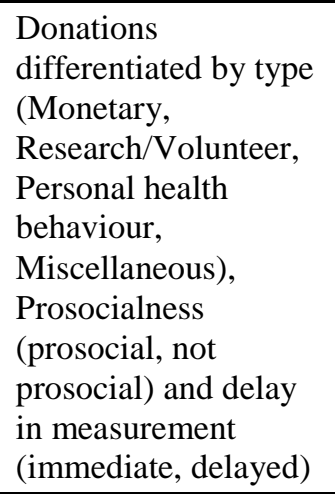 & $\begin{array}{l}\text { Not specified, } \\
\text { references suggest a } \\
\text { mix of lab and field } \\
\text { experiments }\end{array}$ \\
\hline
\end{tabular}




\begin{tabular}{|c|c|c|c|c|c|c|}
\hline Who & Method of persuasion & $\begin{array}{l}\text { Bekkers \& } \\
\text { Wiepking } \\
\text { (2011b) } \\
\text { Mechanism }\end{array}$ & $\begin{array}{l}\text { Channel of } \\
\text { communication }\end{array}$ & Receiver & Outcome measured & $\begin{array}{l}\text { Data collection } \\
\text { context(s) }\end{array}$ \\
\hline $\begin{array}{l}\text { Fromell et } \\
\text { al., } 2020\end{array}$ & $\begin{array}{l}\text { Adding time pressure, } \\
\text { parallel tasks, tiring } \\
\text { tasks, or priming them } \\
\text { to use intuition. }\end{array}$ & Other & $\begin{array}{l}\text { Not specified or } \\
\text { implied }\end{array}$ & $\begin{array}{l}\text { Individuals, usually adults, often } \\
\text { students or Amazon Mechanical } \\
\text { Turk participants }\end{array}$ & $\begin{array}{l}\text { Donations to charities } \\
\text { or other participants } \\
\text { ('players') }\end{array}$ & $\begin{array}{l}\text { Experimental; usually } \\
\text { lab studies }\end{array}$ \\
\hline $\begin{array}{l}\text { Jung et al., } \\
2020\end{array}$ & $\begin{array}{l}\text { Offering a range of } \\
\text { prosocial models }\end{array}$ & Efficacy & $\begin{array}{l}\text { Either direct } \\
\text { observation or via } \\
\text { audio or visual } \\
\text { materials } \\
\end{array}$ & $\begin{array}{l}\text { All ages (children, school-age, } \\
\text { adult) }\end{array}$ & $\begin{array}{l}\text { 'Material help' } \\
\text { (donating money or } \\
\text { tokens [in the case of } \\
\text { children]) }\end{array}$ & $\begin{array}{l}\text { Experimental studies, } \\
\text { conducted in labs, in the } \\
\text { field, and online }\end{array}$ \\
\hline $\begin{array}{l}\text { Larney et } \\
\text { al., } 2019\end{array}$ & Variation in stake sizes & $\begin{array}{l}\text { Costs and } \\
\text { Benefits }\end{array}$ & $\begin{array}{l}\text { Face-to-face apart } \\
\text { from one online } \\
\text { study }\end{array}$ & $\begin{array}{l}\text { Individuals, presumably adults } \\
\text { and mostly students, Western, } \\
\text { Indian, and Chinese samples } \\
\text { were also used } \\
\text { (undifferentiated) }\end{array}$ & $\begin{array}{l}\text { Money offered to } \\
\text { other player(s) }\end{array}$ & $\begin{array}{l}\text { Dictator and ultimatum } \\
\text { games; differentiated by } \\
\text { whether repeated } \\
\text { measures were used; lab } \\
\text { and online experiments }\end{array}$ \\
\hline $\begin{array}{l}\text { Lee et al., } \\
2016\end{array}$ & $\begin{array}{l}\text { Making small requests } \\
\text { for donation / Paltry } \\
\text { contributions; also } \\
\text { coded for use of other } \\
\text { techniques (normative } \\
\text { information, pre-giving, } \\
\text { dialogue induction, } \\
\text { initial request of a small } \\
\text { or large favour), also } \\
\text { coded for whether phase } \\
\text { used was identical to } \\
\text { "even a penny will } \\
\text { help", or a variant }\end{array}$ & $\begin{array}{l}\text { Costs and } \\
\text { Benefits }\end{array}$ & $\begin{array}{l}\text { Face-to-face } \\
\text { interaction, } \\
\text { mediated channels } \\
\text { (written mail or } \\
\text { scenario, } \\
\text { telephone), or } \\
\text { mixed methods }\end{array}$ & $\begin{array}{l}\text { Individuals differentiated by } \\
\text { country (United States, Non- } \\
\text { United States), sex (male, } \\
\text { female, both) and age (student, } \\
\text { adult) }\end{array}$ & $\begin{array}{l}\text { Donation: } \\
\text { Categorized by } \\
\text { (money, product, } \\
\text { time), topic (health, } \\
\text { poverty, animal } \\
\text { protection; } \\
\text { social/educational } \\
\text { event) and time of } \\
\text { action (immediate } \\
\text { donation or pledge) }\end{array}$ & $\begin{array}{l}\text { Experiments in a } \\
\text { subject's home, a public } \\
\text { place, or a laboratory }\end{array}$ \\
\hline $\begin{array}{l}\text { Lee \& } \\
\text { Feeley, } 2017\end{array}$ & $\begin{array}{l}\text { Requesting an odd } \\
\text { donation amount }(17 \mathrm{c} \\
\text { vs. 10c) }\end{array}$ & Awareness & $\begin{array}{l}\text { Not specified or } \\
\text { implied }\end{array}$ & $\begin{array}{l}\text { Mostly adult samples (15/17) } \\
\text { with some students (2/17) }\end{array}$ & $\begin{array}{l}\text { Small monetary } \\
\text { donations ( } 1 \text { study } \\
\text { measured time, which } \\
\text { we did not extract) }\end{array}$ & $\begin{array}{l}\text { Mostly field studies (15 } \\
\text { of 17) }\end{array}$ \\
\hline
\end{tabular}




\begin{tabular}{|c|c|c|c|c|c|c|}
\hline Who & Method of persuasion & $\begin{array}{l}\text { Bekkers \& } \\
\text { Wiepking } \\
\text { (2011b) } \\
\text { Mechanism }\end{array}$ & $\begin{array}{l}\text { Channel of } \\
\text { communication }\end{array}$ & Receiver & Outcome measured & $\begin{array}{l}\text { Data collection } \\
\text { context(s) }\end{array}$ \\
\hline $\mathrm{Lu}, 2016$ & $\begin{array}{l}\text { Effect of giving grants } \\
\text { to non-profit } \\
\text { organisations on } \\
\text { individual donors }\end{array}$ & Altruism & $\begin{array}{l}\text { Not specified or } \\
\text { implied }\end{array}$ & $\begin{array}{l}\text { Individuals, corporations, and } \\
\text { foundations, differentiated by } \\
\text { sector (arts, education and } \\
\text { research, environment, health } \\
\text { care, human services, } \\
\text { international development, and } \\
\text { public benefit), country (US v } \\
\text { Non-US) and organisational } \\
\text { characteristics (age and size) }\end{array}$ & $\begin{array}{l}\text { Donations to non- } \\
\text { profit by individuals, } \\
\text { corporations, and } \\
\text { foundations }\end{array}$ & $\begin{array}{l}\text { Analysis of secondary } \\
\text { data }\end{array}$ \\
\hline
\end{tabular}

\begin{tabular}{|c|c|c|c|c|c|c|}
\hline $\begin{array}{l}\text { Nettle et al., } \\
2013\end{array}$ & $\begin{array}{l}\text { Watching eyes during } \\
\text { donation opportunity }\end{array}$ & Reputation & $\begin{array}{l}\text { Not specified, } \\
\text { method implies } \\
\text { that online and } \\
\text { face-to-face were } \\
\text { used }\end{array}$ & $\begin{array}{l}\text { Individuals, presumably adults } \\
\text { and mostly students } \\
\text { (undifferentiated) }\end{array}$ & $\begin{array}{l}\text { Money offered to } \\
\text { other player(s) }\end{array}$ & $\begin{array}{l}\text { Dictator game, } \\
\text { references imply lab } \\
\text { and online experiments }\end{array}$ \\
\hline $\begin{array}{l}\text { Northover et } \\
\text { al., } 2017\end{array}$ & $\begin{array}{l}\text { Artificial surveillance } \\
\text { cues (resembled a } \\
\text { watching face or eyes; } \\
\text { generally, photographs } \\
\text { or stylized images of } \\
\text { eyes) }\end{array}$ & Reputation & $\begin{array}{l}\text { Not specified, } \\
\text { method implies } \\
\text { that online and } \\
\text { face-to-face were } \\
\text { used }\end{array}$ & $\begin{array}{l}\text { Individuals, presumably adults } \\
\text { and mostly students } \\
\text { (undifferentiated) }\end{array}$ & $\begin{array}{l}\text { Generosity: giving } \\
\text { material resources to } \\
\text { others, for reasons } \\
\text { other than direct } \\
\text { reciprocity, without } \\
\text { expecting anything } \\
\text { from those others in } \\
\text { return }\end{array}$ & $\begin{array}{l}\text { Social discounting } \\
\text { tasks, economic games, } \\
\text { and charity donations; }\end{array}$ \\
\hline
\end{tabular}




\begin{tabular}{|c|c|c|c|c|c|c|}
\hline Who & Method of persuasion & $\begin{array}{l}\text { Bekkers \& } \\
\text { Wiepking } \\
\text { (2011b) } \\
\text { Mechanism }\end{array}$ & $\begin{array}{l}\text { Channel of } \\
\text { communication }\end{array}$ & Receiver & Outcome measured & $\begin{array}{l}\text { Data collection } \\
\text { context(s) }\end{array}$ \\
\hline $\begin{array}{l}\text { Peloza \& } \\
\text { Steel, 2005 }\end{array}$ & $\begin{array}{l}\text { Giving tax deductions } \\
\text { on donations, } \\
\text { differentiated by } \\
\text { permanency of tax } \\
\text { (permanent or } \\
\text { temporary) }\end{array}$ & $\begin{array}{l}\text { Costs and } \\
\text { Benefits }\end{array}$ & $\begin{array}{l}\text { Not specified or } \\
\text { implied }\end{array}$ & $\begin{array}{l}\text { Tax paying adults differentiated } \\
\text { by income (above } \$ 100,000 \text { in } \\
\text { earnings and below), and } \\
\text { itemization of charitable } \\
\text { donations (itemizer, non- } \\
\text { itemizer) }\end{array}$ & $\begin{array}{l}\text { Private philanthropy, } \\
\text { differentiated by type } \\
\text { of donation (donation } \\
\text { or bequest) }\end{array}$ & $\begin{array}{l}\text { Analysis of secondary } \\
\text { data differentiated by } \\
\text { source type (panel or } \\
\text { cross-sectional, and tax- } \\
\text { filer or survey) }\end{array}$ \\
\hline $\begin{array}{l}\text { Rand et al., } \\
2016\end{array}$ & $\begin{array}{l}\text { Promoting either } \\
\text { intuition or deliberation } \\
\text { during donation } \\
\text { opportunity }\end{array}$ & Other & $\begin{array}{l}\text { Not specified, } \\
\text { method implies } \\
\text { that online and } \\
\text { face-to-face were } \\
\text { used }\end{array}$ & $\begin{array}{l}\text { Individuals differentiated by sex } \\
\text { (male or female) and } \\
\text { identification with sex role } \\
\text { (male versus female) to assess } \\
\text { interactions }\end{array}$ & $\begin{array}{l}\text { Money offered to } \\
\text { other player(s) }\end{array}$ & $\begin{array}{l}\text { Dictator game, } \\
\text { references imply lab } \\
\text { and online experiments }\end{array}$ \\
\hline $\begin{array}{l}\text { Salido- } \\
\text { Andres et } \\
\text { al., } 2020\end{array}$ & Various methods & & $\begin{array}{l}\text { Online and } \\
\text { blended (online \& } \\
\text { offline) donation- } \\
\text { based } \\
\text { crowdfunding } \\
\text { campaigns }\end{array}$ & Individuals from $20+$ countries & $\begin{array}{l}\text { Donations to } \\
\text { crowdfunding projects }\end{array}$ & Field studies \\
\hline $\begin{array}{l}\text { Sparks \& } \\
\text { Barclay, } \\
2013\end{array}$ & $\begin{array}{l}\text { Watching eyes during } \\
\text { donation opportunity } \\
\text { (short } v \text { prolonged } \\
\text { exposure) }\end{array}$ & Reputation & $\begin{array}{l}\text { Face-to-face in } \\
\text { the lab, field } \\
\text { studies (e.g., bus } \\
\text { stop, } \\
\text { supermarket), and } \\
\text { one online study }\end{array}$ & $\begin{array}{l}\text { Individuals, presumably adults } \\
\text { and mostly students }\end{array}$ & Money offered & $\begin{array}{l}\text { Dictator game, } \\
\text { references imply lab } \\
\text { and online experiments }\end{array}$ \\
\hline $\begin{array}{l}\text { Xu \& } \\
\text { Huang, } 2020\end{array}$ & $\begin{array}{l}\text { Gain-framed vs. loss- } \\
\text { framed messages }\end{array}$ & $\begin{array}{l}\text { Costs and } \\
\text { Benefits }\end{array}$ & $\begin{array}{l}\text { Not specified or } \\
\text { implied }\end{array}$ & Both adults and students & $\begin{array}{l}\text { Donations provided } \\
\text { (or intention to } \\
\text { donate) }\end{array}$ & $\begin{array}{l}\text { Both lab and field } \\
\text { experiments }\end{array}$ \\
\hline
\end{tabular}

